\title{
Essay
}

\section{Speculative Undertakings: Rate Regulation as a Branch of Corporate Finance}

\author{
James Ming Chen ${ }^{\dagger}$
}

The law of regulated industries, particularly the obligation to secure "just and reasonable rates" for regulated services, is a highly specialized application of financial economics. Ratemaking, bluntly put, represents a regulatory exercise in capital asset pricing. As a matter of economics, this Essay describes ratemaking as a variation on the financial theme of uncertainty. As a matter of law, this Essay describes legal principles guiding the regulatory determination of the rate of return on utility property. It analyzes two valuation methods derived from the 1923 Bluefield Water Works decision ("attracting capital" and "comparable earnings"), as well as a third approach based on the capital asset pricing model. Discretionary elements in rate regulation make it impossible to wholly alleviate uncertainty in the pricing of infrastructure. Rate regulation therefore constitutes a speculative undertaking in its own right.

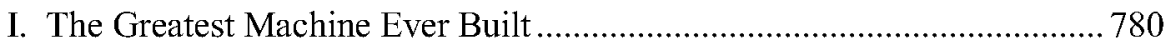

II. Ratemaking as Regulatory Asset Pricing ............................................... 783

A. "Public" Utilities, Private Investors .......................................... 783

B. A Generalized Model of Financial Uncertainty............................788

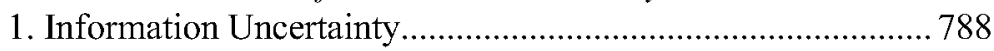

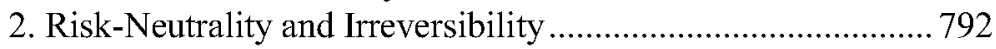

III. Conventional Rate of Return Determinations...................................... 795

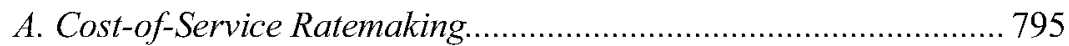

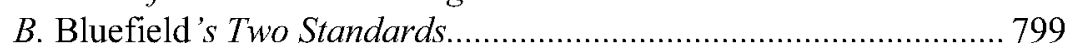

IV. Regulatory Asset Pricing After Bluefield ............................................ 801

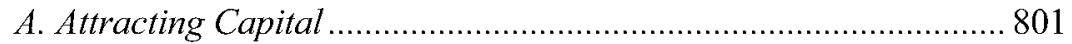

1. Discounted Cash Flow ................................................................ 801

2. Gordon Growth Model..................................................... 802

$\dagger$ Justin Smith Morrill Chair in Law, Michigan State University; Of Counsel, Technology Law Group of Washington, D.C.; Visiting Scholar, University of Zagreb, Faculty of Economics and Business (Ekonomski Fakultet, Sveučilište u Zagrebu). I benefited from a workshop at Michigan State on January 24, 2018. Barbara Bean, Jurica Šimurina, Tomislav Gelo, José-María Montero Lorenzo, Gema Fernández-Avilés Calderón, and Gil Grantmore provided helpful comments. Special thanks to Heather Elaine Worland Chen. 
3. Efficient Market Hypothesis ................................................... 804

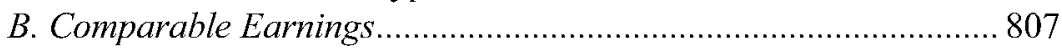

V. The Capital Asset Pricing Model ............................................................ 809

A. DCF and CAPM as Benchmarks Within a Zone of Reasonableness

B. A Formal Description of the CAPM ........................................ 811

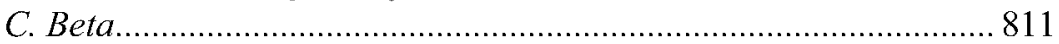

VI. Utility Regulation as a Speculative Undertaking in Its own Right......... 814

\section{The Greatest Machine Ever Built}

In a "world . . . . . lit by lightning," "time is the longest distance between two points." As Anthropocene excesses darken humanity's prospects, ${ }^{2}$ technological innovation strives to keep humans lit, warm, and connected. Law may not physically prepare the world for climate change, but it can dictate how low- and zero-carbon electrical infrastructure will be financed. This Essay analyzes public utility regulation as an application of financial economics.

The electrical grid that illuminates the world deserves nearly every superlative used to describe it. The electrical power system has been hailed as the "supreme engineering achievement of the 20th century," the "world's biggest, most complex machine," and perhaps even "the most complex machine ever made." Electricity can neither "be stored on any significant scale" nor be directed in the fashion of "classic switched networks." Base load generation remains necessary because humans demand electricity precisely when solar

1. Robert Bray, Introduction to TENNESSEE WILLIAMS, THE GLASS MENAGERIE 97 (1999).

2. See, e.g., Bruce D. Smith \& Melinda A. Zeder, The Onset of the Anthropocene, 4 ANTHROPOCENE 8 (2013); Jan Zalasiewicz et al., Stratigraphy of the Anthropocene, 369 PHIL. TrANSACTIONS ROYAL SOC'Y A 1036 (2011); Jan Zalasiewicz, Mark Williams, Will Steffen \& Paul Crutzen, The New World of the Anthropocene, 44 ENVTL. SCI. \& TECH. 2228 (2010).

3. GeORge CONSTABLE \& Bob SOMERVILle, A CENTURy of INNOVATION: TWENTY ENGINEERING ACHIEVEMENTS THAT TRANSFORMED OUR LIVES 1 (2003); accord, e.g., MASS. INST. OF TECH., THE FUTURE OF THE ELECTRIC GRID 1 (2011); X. Andy Sun, Robust Optimization in Electric Power Systems, in ADVANCES AND TRENDS IN OPTIMIZATION WITH ENGINEERING APPLICATIONS 357-66 (Tamøs Terlaky et al. eds., 2017) (describing the grid as "one of the most complex human-made systems").

4. S. Massoud Amin, Securing the Electricity Grid, 40 BRIDGE 1, 14 (2010).

5. Phillip F. SCHEwe, The Grid: A Journey Through the HeART of OuR ELECTRIFIED WORLD 1 (2007).

6. William Boyd, Public Utility and the Low-Carbon Future, 61 UCLA L. REV. 1614, $1626(2014)$. 
energy, arguably the greatest ecosystem service, ${ }^{7}$ is unavailable. ${ }^{8}$ By balancing generation and load "in real time," the "sophisticated systems" that "ensure continuous delivery of reliable electric service" represent "the ultimate "just-intime' manufacturing process, where supply must be produced to meet demand in real time." $" 10$

The American economy depends on electrical infrastructure, ${ }^{11}$ the operation of "millions of component parts and individual devices ... in "electromagnetic unity.", 12 Engineering challenges will become more formidable as climate change forces the electrical system to adopt low- or zerocarbon sources of generation. The precise "mix of technologies, practices, and behaviors [that] will deliver substantial decarbonization" remains shrouded in "significant uncertainty." ${ }^{13}$ Contributions by distributed generation, ${ }^{14}$ electrical storage, ${ }^{15}$ nuclear energy, ${ }^{16}$ and carbon capture and storage ${ }^{17}$ to name only four possibilities - elude precise quantification. ${ }^{18}$ Even the best established of these prospects, nuclear energy, ${ }^{19}$ requires "enormous facilities with high construction

7. See, e.g., CONSERVING AND VALUING ECOSYSTEM SERVICES AND BIODIVERSITY (K.N. Ninan ed., 2009); NATURE's SERVICES: SOCIETAL DEPENDENCE ON NATURAL ECOSYSTEMS (Gretchen C. Daily ed., 1997); PETER H. RAVEN ET AL., TEAMING WITH LIFE: INVESTING IN SCIENCE TO UNDERSTAND AND USE AMERICA's LiVING CAPITAL (1999); Graciela Chichilnisky \& Geoffrey Heal, Economic Returns from the Biosphere, 391 NATURE 629 (1998); Robert Costanza et al., The Value of Ecosystem Services: Putting the Issues in Perspective, 25 ECOL. ECON. 67 (1998).

8. See Francesco Meneguzzo, Rosaria Ariminna, Lorenzo Albanese \& Mario Pagliaro, The Great Solar Boom: A Global Perspective into the Far Reaching Impact of an Unexpected Energy Revolution, 3 ENERGY SCl. \& ENG'G 499, 506 (2015). See generally Dong Gu Choi, Sang Yong Park, Nyun-Bae Park \& Jong Chul Hong, Is the Concept of "Grid Parity" Defined Appropriately to Evaluate the Cost-Competitiveness of Renewable Energy Technologies?, 86 ENERGY POL'Y 718 (2015) (comparing the cost of generation technologies that differ in their ability to meet base loads).

9. Boyd, supra note 6 , at $1626-27$.

10. Paul L. Joskow, Creating a Smarter U.S. Electricity Grid, 26 J. ECON. PERSP. 29, 33 (2012); accord Boyd, supra note 6, at 1627 \& n.36.

11. See, e.g., Lois R. Lupica, Transition Losses in the Electric Power Market: A Challenge to the Premises Underlying the Arguments for Compensation, 52 RUTGERS L. REV. 649, 652 n.6 (2000).

12. William Boyd \& Ann E. Carlson, Accidents of Federalism: Ratemaking and Policy Innovation in Public Utility Law, 63 UCLA L. REV. 810, 883 (2016) (quoting Fed. Power Comm'n v. Fla. Power \& Light Co., 404 U.S. 453, 460 (1972)).

13. Id. at 887 .

14. See Amy L. Stein, Distributed Reliability, 87 U. COLO. L. REV. 887 (2016).

15. See Amy L. Stein, Reconsidering Legal Uncertainty: Making a Case for Energy Storage, 41 FLA. ST. U. L. REV. 697 (2014).

16. See Emily Hammond \& David B. Spence, The Regulatory Contract in the Marketplace, 69 VAND. L. REV. 141, 166-68 (2016) (comparing the impact of coal, natural gas, and nuclear energy).

17. See, e.g., Berend Smit, JefFrey A. Reimer, Curtis M. Oldenburg \& IAn C. BOURG, INTRODUCTION TO CARBON CAPTURE AND SEQUESTRATION (2014); JENNIFER WILCOX, CARBON CAPTURE (2012); Alexandra B. Klass \& Elizabeth J. Wilson, Climate Change, Carbon Sequestration, and Property Rights, 2010 U. ILL. L. REV. 363.

18. See Boyd \& Carlson, supra note 12 , at 887 .

19. See Order Adopting a Clean Energy Standard, 331 P.U.R.4th 357 (N.Y. Pub. Serv. Comm'n, Aug. 1, 2016) (discussing "zero-emissions nuclear generation resources as a bridge to the clean energy future" where " $50 \%$ of New York's electricity is to be generated by renewable sources by 2030 as part of a strategy to reduce statewide greenhouse gas emissions by $40 \%$ by 2030 "). 
costs." ${ }^{20}$ A future low- or zero-carbon electrical system "will have a higher capital intensity."21

Maintaining the grid, let alone decarbonizing it, poses more than merely technological obstacles. Ensuring a constant flow of electricity also presents great challenges to law and finance. "[A]ny electricity that enters the grid immediately becomes a part of a vast pool of energy that is constantly moving in interstate commerce." 22 As public utility law continues its "great transformation," 23 its "creative force" will compel us "to transform the most complex machine ever built into something vastly cleaner, more distributed, and more interactive. $" 24$

The law of regulated industries endeavors to lay the foundations of civilization - or at least to finance the most ambitious forms of infrastructure. Through Gilded Age legislation addressing industries "affected with a public interest," 25 the law of regulated industries has built "intricate and pervasive systems which furnish light, heat, power, water, transportation, and communication." 26 For an ambitious society seeking to "catch the last subway, the streetcar, the bus," "[o] ne job is not enough, one life is not enough." the legal basis of "Infrastructure U.S.A.," public utility law has permitted "a degree of experimentation in governmental direction of economic activity ... beyond any historical parallel., ${ }^{928}$

This Essay explains the obligation to ensure "just and reasonable" regulatory rates as a specialized application of financial economics. Ratemaking represents a legal exercise in capital asset pricing. Part II describes ratemaking as a variant of financial uncertainty. Part III reviews the law governing the rate of return on utility property. Part IV analyzes two valuation methods derived from the Bluefield Water Works decision ("attracting capital" and "comparable earnings"). ${ }^{29}$ Part V presents a third approach based on the capital asset pricing model. Part VI concludes that discretionary elements in rate regulation make it

20. Lucas W. Davis, Prospects for Nuclear Power, 26 J. ECON. PERSP. 49, 53 (2012); see also Boyd \& Carlson, supra note 12, at 844 ("Fission-based reactors are enormously complicated machines ... They take years to build and cost huge sums of money.").

21. Boyd, supra note 6, at 1634 .

22. New York v. FERC, 535 U.S. 1, 7 (2002)

23. See Joseph D. Kearney \& Thomas W. Merrill, The Great Transformation of Regulated Industries Law, 98 COLUM. L. REV. 1323 (1998).

24. Boyd \& Carlson, supra note 12 , at 893.

25. Munn v. Illinois, 94 U.S. 113 (1877).

26. FELIX Frankfurter, THE PUBliC AND ITS GOVERNMENT 81 (1930); accord Boyd, supra note 6 , at 1638 .

27. JoHn DOS PASSOS, U.S.A. 1 (1996).

28. Felix Frankfurter \& Henry M. Hart, Jr., Rate Regulation, in 13 ENCYCLOPAEDIA OF THE SOCIAL SCIENCES 104 (Edwin R.A. Seligman \& Alvin Johnson eds., 1934); accord William J. Novak, Law and the Social Control of American Capitalism, 60 EMORY L.J. 377, 404 (2010).

29. Bluefield Water Works \& Improvement Co. v. Public Serv. Comm'n, 262 U.S. 679 (1923). 
impossible to wholly alleviate uncertainty in utility pricing. Rate regulation therefore constitutes a speculative undertaking in its own right.

\section{Ratemaking as Regulatory Asset Pricing}

\section{A. "Public" Utilities, Private Investors}

Rate regulation is properly understood as a branch of public finance. The law of regulated industries, like taxation, not only "defray[s] the cost of services" that "the market would not provide in the desired quantity and at the desired price," but also "transfer[s] money" between groups. ${ }^{30}$ Differences between "public ownership" and "profit-seeking management" have predictable, systematic "effect $[\mathrm{s}]$. . . . . on the price behavior of government firms." " ${ }^{13}$ Public intervention in energy, transportation, and communications markets should be treated as instances of the Modigliani-Miller theorem. ${ }^{32}$ Capital structureimplemented through debt, preferred stock, and common stock $^{33}$ - is merely a theoretical abstraction that arranges the order of claims against a firm without affecting fundamental valuation. ${ }^{34}$

In the United States, most "networks that distribute products or services over geographic space" are owned by private investors and operated for profit. ${ }^{35}$ Investor-owned utilities comprise three-quarters of America's trillion-dollar electrical power system. ${ }^{36}$ Extensive private ownership converts the term "public utility" into an egregious misnomer. Utilities are "public" in the pragmatic sense that they satisfy mass needs, like "traditional governmental functions of police and justice," and do not become "less so when these services are rendered by private enterprise." 37

From a global perspective, it is "striking that the United States was the only country that was able to maintain private ownership of most of its utilities

30. Richard A. Posner, Taxation by Regulation, 2 BELL J. ECON. \& MGMT. SCI. 22, 28-29 (1971); cf. Compania General de Tabacos v. Collector of Internal Revenue, 275 U.S. 87, 100 (1927) (Holmes, J., dissenting) (describing taxes as the price "we pay for civilized society").

31. Sam Peltzman, Pricing in Public and Private Enterprises: Electric Utilities in the United States, 14 J.L. \& ECON. 109, 111 (1971).

32. See Franco Modigliani \& Merton Miller, The Cost of Capital, Corporate Finance, and the Theory of Investment, 48 AM. ECON. REV. 261 (1958).

33. See N.C. Utils. Comm'n v. FERC, 42 F.3d 659, 661 (D.C. Cir. 1994) (identifying the contribution of long-term debt, preferred stock, and common stock to a pipeline's capital structure).

34. See John C. Cox \& Stephen A. Ross, The Valuation of Options for Alternative Stochastic Processes, 3 J. FIN. ECON. 145, 145 (1976) (describing debt and equity as "simply financial tools ... offering alternative modes of ownership of the same economic stream of returns"). AND DISCRETION 4 (2003).

35. JOSÉ A. GÓMEZ-IBÁÑEZ, REGULATING INFRASTRUCTURE: MONOPOLY, CONTRACTS,

36. See Ron Bing ET AL., Practicing Risk-AWARE EleCtricity Regulation: What EVERY STATE REGULATOR NEEDS TO KNOW 14 (2012) (reporting $\$ 765$ billion in investor-owned utilities, $\$ 200$ billion in municipal utilities, and $\$ 112$ billion in rural electric cooperatives).

37. Fed. Power Comm'n v. Hope Nat. Gas Co., 320 U.S. 591, 625 (1944) (Frankfurter, J., dissenting). 
throughout the twentieth century."38 Other countries typically commit infrastructure to the public sector. As countries grow, utilities often draw hostile attention as "the first nationally prominent big businesses to emerge" from an industrial revolution. ${ }^{39}$ The United States has eluded these political dynamics. True to an "energetic and articulate" culture that champions capitalism over socialism with "remarkable" intensity, ${ }^{40}$ America embraces private ownership of infrastructure.

A mostly private electrical power system may struggle to replace climatealtering fuels. As commentators have noted, to "limit[] the anthropogenic increase in global mean surface temperature to less than 2 degrees Celsius," the United States must reduce its greenhouse gas "emissions $80 \%$ below 1990 levels by $2050 . " 41$ "[C] $]$ urrent wholesale power markets ... appear limited in their ability to support investments in large, capital-intensive, low-carbon generation facilities such as nuclear or coal plants with carbon capture and storage., ${ }^{, 42}$ The transition "to an 80 percent renewables future will require investing roughly $\$ 50$ 70 billion per year over the next decade," perhaps "between $\$ 100$ and $\$ 200$ billion per year as we approach $2050 .{ }^{.43}$ Low-carbon conversion will demand sums "roughly two to five times larger than current levels of investment in new transmission and generation assets." 44

The "higher capital intensity of a low-carbon electricity system," relative to "the current fossil-based system," compounds the risk inherent in "the longlived nature of many of these assets." ${ }^{245}$ Even more than economies of scale ${ }^{46}$ or scope ${ }^{47}$ the asset-specificity of "durable and immobile investments" is "the defining characteristic[] of infrastructure monopolies." 48 Whether limited by geography, time, or embedded human capital, investments sunk into assets specific to one transaction can be neither recovered nor transferred. ${ }^{49}$ Scale,

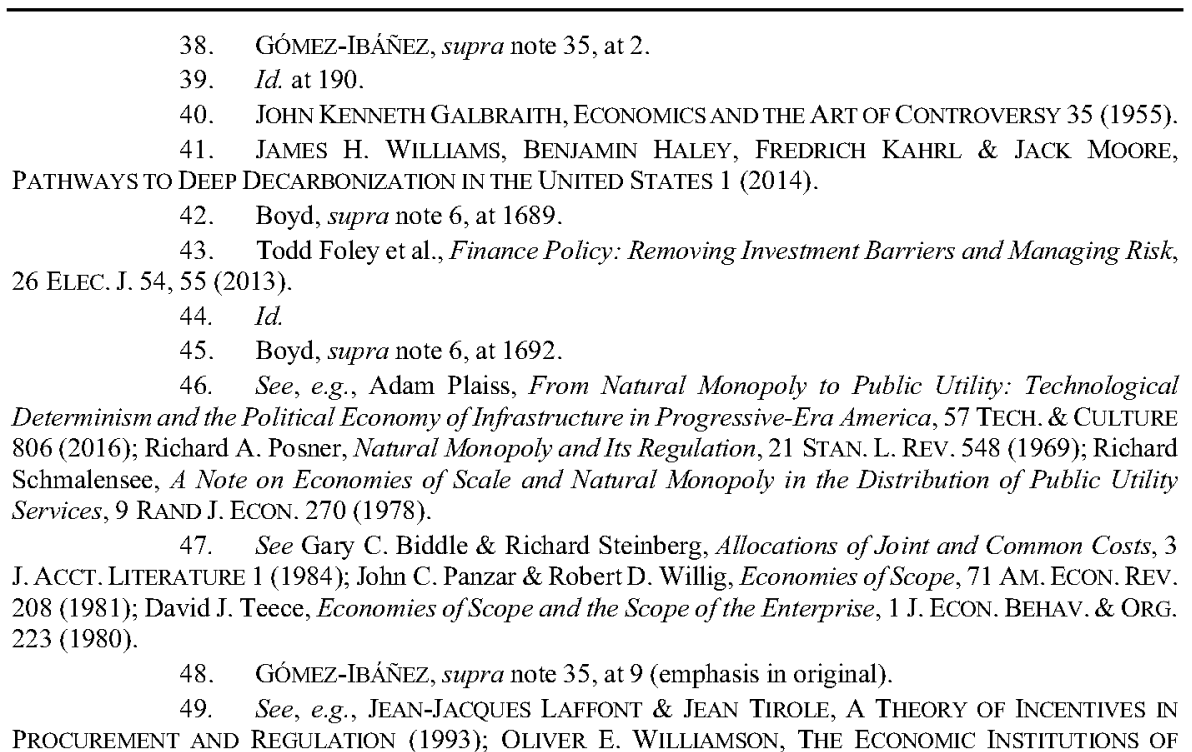


durability, and specialization all exacerbate the vulnerability of infrastructure to opportunism - by suppliers, customers, competitors, and the government. ${ }^{50}$

Extensive historical investments in infrastructure represent sunk costs in a technologically dynamic marketplace responding exclusively to current costs. ${ }^{51}$ Economic theory prescribes a crisp response to sunk costs: Ignore them. Though sunk costs "are usually visible, . . . they should always be ignored when making economic decisions." ${ }^{52}$ Economists evaluate cost on a wholly prospective basis, ${ }^{53}$ costs already incurred "do not affect decisions on price and quantity."

Heavy reliance on technological innovation in industries such as broadband communications and the post-carbon electrical system ${ }^{55}$ demands a focus on "forward-looking costs" to the exclusion of "historical, booked costs" allegedly stranded by economic, technological, or regulatory change. ${ }^{56}$ Whatever their legality, ${ }^{57}$ legislative and administrative efforts to recover "stranded" investments are the economic "antithesis of competition."

But today's forward-looking investments are tomorrow's sunk costs. ${ }^{59}$ The prospect that infrastructure may be stranded by technological or political change affects the marginal propensity to invest. One prime example is the prospect that keeping the anthropocentric contribution to global temperatures below $2^{\circ} \mathrm{C}$ will "eliminat[e] virtually all natural gas use by $2050 . "{ }^{\circ 0}$ The theory of contestable markets, a description covering vast turf between perfect competition and natural

CAPITALISM: FIRMS, MARKETS, RELATIONAL CONTRACTING (1996); Paul L. Joskow, Assset-Specificity and the Structure of Vertical Relationships: Empirical Evidence, 4 J.L. ECON. \& ORG. 95 (1988); Oliver E. Williamson, Credible Commitments: Using Hostages to Support Exchange, 77 AM. ECON. REV. 519 (1983); Oliver E. Williamson, The Economics of Organization: The Transaction Cost Approach, 87 AM. J. SOC. 548 (1981).

50. See Benjamin Klein et al., Vertical Integration, Appropriable Rents, and the Competitive Contracting Process, 21 J.L. \& ECON. 297, 298-300 (1978).

51. Alenco Commc'ns, Inc. v. FCC, 201 F.3d 608, 615 (5th Cir. 2000).

52. ROBERT S. PINDYCK \& DANIEL L. RUBINFELD, MiCROECONOMICS $\$ 7.2$, at 221 ( 9 th ed. 2017). But cf. R.H. Strotz, Myopia and Inconsistency in Dynamic Utility Maximization, 23 REV. ECON. STUD. 165, 167 (1956) (raising "the possibility that a person is not indifferent to his consumption history but enjoys his memories of it").

53. See Verizon Commc'ns, Inc. v. FCC, 535 U.S. 467, 499 n.17 (2002).

54. RICHARD A. POSNER, ECONOMIC ANALYSIS OF LAW $\$ 1.1$, at 7 (3d ed. 1986).

55. MCI Commc'ns Corp. v. American Tel. \& Tel. Co., 708 F.2d 1081, 1117 (7th Cir.

1983).

56. Alenco Commc'ns, Inc. v. FCC, 201 F.3d 608, 615 (5th Cir. 2000).

57. Compare William J. Baumol \& J. Gregory Sidak, Stranded Costs, 18 HARV. J.L. \& PUB. POL'Y 835 (1995) (favoring stranded cost recovery), with Emily Hammond \& Jim Rossi, Stranded Costs and Decarbonization, 82 BROOK. L. REV. 645 (2017) (urging a tempered approach).

58. Cajun Elec. Power Coop., Inc. v. FERC, 28 F.3d 173, 179 (D.C. Cir. 1994).

59. See Joseph E. Stiglitz, Technological Change, Sunk Costs, and Competition, 3 BROOKINGS PAPERS ON ECON. ACTIVITY 883 (1987).

60. STEVE WEISSMAN, CENTER FOR SUSTAINABLE ENERGY, NATURAL GAS AS A BRIDGE FUEL: MEASURING THE BRIDGE 8 (2016); accord Hammond \& Rossi, supra note 57, at 668; see WILLIAMS, HALEY, KAHRL \& MOORE, supra note 41 , at 1 (reporting the $2^{\circ} \mathrm{C}$ limit as a goal). 
monopoly, ${ }^{61}$ recognizes that sunk costs can impede future entry. ${ }^{62}$ Because an "investment that cannot easily be moved elsewhere is an impediment to exit," sunk costs pose "a prime obstacle to entry."

"Hit-and-run" entry in contestable markets, where investments are not irretrievably committed, imposes competitive discipline and relaxes the need for regulatory intervention. ${ }^{64}$ Outside structurally contestable industries such as transportation and mobile telecommunications, ${ }^{65}$ however, incumbents defend sunk investments through "sit-and-gun" behavior, including predatory pricing. ${ }^{66}$

Sunk costs and contestable markets are ideas drawn from microeconomics and from industrial organization. ${ }^{67}$ The principle of "costly reversibility" translates these ideas into corporate finance. Reversals of investment in physical $^{68}$ and human ${ }^{69}$ capital are never free. "Costly reversibility implies that firms face higher costs in cutting than in expanding capital." 70 The reluctance to build irretrievably sunk infrastructure, to say nothing of private investors' recalcitrance to invest absent reassurance that they will recover their capital, represents a special case of costly reversibility.

The decarbonized future therefore requires not only technological but also legal and financial ingenuity. Investment risk of this magnitude poses financial

61. See, e.g., William J. Baumol, Contestable Markets: An Uprising in the Theory of Industry Structure, 72 AM. ECON. REV. 1 (1982); Robert D. Cairns \& Dhanayshar Mahabir, Contestability: A Revisionist View, 55 ECONOMICA 269 (1988); Avinash Dixit, Recent Developments in Oligopoly Theory, 72 AM. ECON. REV. 12 (1982); William G. Shepherd, "Contestability" vs. Competition, 74 AM. ECON. REV. 572 (1984); Michael Spence, Contestable Markets and The Theory of Industry Structure: A Review Article, 20 J. ECON. LIT. 981 (1983).

62. See William J. BAuMOL ET AL., CONTESTABle Markets AND THE THEORY OF INDUSTRY STRUCTURE 290-92 (1982).

63. Elizabeth E. Bailey \& William J. Baumol, Deregulation and the Theory of Contestable Markets, 1 YALE J. ON REG. 111, 123-24 (1984).

64. See id. at 114-15, 121-22. See generally Elizabeth E. Bailey, Contestability and the Design of Regulatory and Antitrust Policy, 71 AM. ECON. REV. 179 (1981) (extending this idea to antitrust as well as the formal regulation of entry and rates).

65. See Bailey \& Baumol, supra note 63, at 123-36; Elizabeth E. Bailey \& John C. Panzar, The Contestability of Airline Markets During the Transition to Deregulation, 44 LAW \& CONTEMP. PROB. 128 (1981); William B. Tye, The Applicability of the Theory of Contestable Markets to Rail/Water Carrier Mergers, LOGISTICS \& TRANSP. REV., March 1985, at 57.

66. See Janusz A. Ordover \& Robert D. Willig, An Economic Definition of Predation: Pricing and Product Innovation, 91 Y ALE L.J. 8 (1981); William G. Shepherd, Entry Barriers, Contestability, and Predatory Pricing, 46 REVUE D’ÉCONOMIE INDUSTRIELLE 1 (1988).

67. See AVINASH K. DIXIT \& ROBERT S. PINDYCK, INVESTMENT UNDER UNCERTAINTY (1994); Andrew B. Abel, Optimal Investment Under Uncertainty, 73 AM. ECON. REV. 228-233 (1983) Andrew B. Abel \& Janice C. Eberly, A Unified Model of Investment Under Uncertainty, 84 AM. ECON. REV. 1369-1384 (1994); Andrew B. Abel \& Janice C. Eberly, Optimal Investment with Costly Reversibility, 63 REV. ECON. STUD. 581-593 (1996).

68. See Russell W. Cooper \& John C. Haltiwanger, On the Nature of Capital Adjustment Costs, 73 REV. ECON. STUD. 611-633 (2006); Valerie A. Ramsey \& Matthew D. Shapiro, Displaced Capital: A Study of Aerospace Plant Closings, 109 J. POL. ECON. 958-992 (2001).

69. See Stephen J. Nickell, Dynamic Models of Labour Demand, in 1 HANDBOOK OF LABOR ECONOMICS 473-524, 473-74 (Orley C. Ashenfelter \& Richard Layard eds., 1986); F.M. Scherer, Research and Development Resource Allocation and Rivalry, 81 Q.J. ECON. 359 (1967).

70. Lu Zhang, The Value Premium, 60 J. FIN. 67, 68 (2005). 
challenges beyond the conventional regulatory toolkit. ${ }^{71}$ Takings cases barring allegedly "confiscatory ratemaking"" can do no more than "prevent governmental destruction of existing economic values."73 The confiscatory ratemaking concept "cannot be applied to insure values, or to restore values that have been lost by the operation of economic forces." for "socializ[ing] the costs of ... investments" in low-carbon generation, "whether through rates, subsidies or some combination," private investors "are unlikely to provide financing on favorable terms." Alarmingly, "liberalized electricity markets" may be incompatible with a low-carbon future. ${ }^{76}$

To the extent that governments build or own infrastructure, regulatory pricing principles will also control. Rate regulation governs public and quasipublic enterprises, such as the Postal Service ${ }^{77}$ and the Bonneville Power Administration. ${ }^{78}$ Publicly owned elements of tomorrow's zero-carbon electrical system will surely be priced "with a view to encouraging the widest possible diversified use of electric power at the lowest possible rates to consumers."79 Within any system of public finance seeking to spur growth, ${ }^{80}$ especially one heeding the "golden rule" that government borrowing should never exceed net capital formation, ${ }^{81}$ balancing private and public investment will prove crucial to stabilizing rates of return. ${ }^{82}$

71. See Robert Gross et al., Risks, Revemues, and Investment in Electricity Generation: Why Policy Needs to Look Beyond Costs, 32 ENERGY ECON. 796 (2010).

72. Conventional wisdom traces the confiscatory ratemaking doctrine, somewhat misleadingly, to Smyth v. Ames, 169 U.S. 466 (1898). See, e.g., 2 JAMES C. BONRIGHT, VALUATION OF PROPERTY 1095-96 (1937); John N. Droback, From Turnpike to Nuclear Power: The Constitutional Limits on Utility Rate Regulation, 65 B.U. L. REV. 65, 75-76, 80 n.65 (1985); Robert L. Hale, Does the Ghost of Smyth v. Ames Still Walk?, 55 HARV. L. REV. 1116, 1120 (1942); Stephen A. Siegel, Understanding the Lochner Era: Lessons from the Controversy over Railroad and Utility Rate Regulation, 70 VA. L. REV. 187, 216-23 (1984).

73. Market St. Ry. v. R.R. Comm'n, 324 U.S. 548, 567 (1945).

74. Id.

75. Boyd, supra note 6, at 1690.

76. David M. Newberry, Reforming Competitive Electricity Markets to Meet Environmental Targets, 1 ECON. ENERGY \& ENVTL. POL'Y 69, 71 (2012).

77. See, e.g., Nat'l Ass'n of Greeting Card Publishers v. United States Postal Serv., 462 U.S. 810 (1983) (assigning to the Postal Rate Commission the primary responsibility for setting postage rates under the Postal Reorganization Act, 39 U.S.C. $\$ 3622$ (b) (2018)); Mail Order Ass'n of Am. v. United States, 2 F.3d 408 (D.C. Cir. 1993).

78. See 16 U.S.C. $\S 839 \mathrm{e}(\mathrm{a})(2)$ (2018) (setting rates within the Bonneville Power Administration so "that such rates . . . are sufficient to assure repayment of the Federal investment ... over a reasonable number of years [and] . . . are based upon the Administrator's total system costs"); $c f$. Cal. Energy Comm'n v. Bonneville Power Admin., 909 F.2d 1298, 1307-08 (9th Cir. 1990) (recognizing that the BPA need not "always charge the lowest possible rates").

79. Alcoa, Inc. v. Bonneville Power Admin., 698 F.3d 774, 789 (9th Cir. 2012) (quoting 16 U.S.C. $\$ 838 \mathrm{~g}(1)(2018))$.

80. See Koishi Futagami et al., Dynamic Analysis of Endogenous Growth Model with Public Capital, 95 SCAND. J. ECON. 607 (1993).

81. See Fabrizio Balassone \& Daniele Franco, Public Investment, the Stability Pact and the "Golden Rule", 21 FisCAL STUD. 207 (2000).

82. See Toshiki Tamai, Public Investment, the Rate of Return, and Optimal Fiscal Policy in a Stochastically Growing Economy, 49 J. MACROECON. 1 (2016). 
The 2016 Supreme Court case of Hughes v. Talen Energy Marketing, LLC ${ }^{83}$ limited states' efforts to promote the construction of generation capacity by promising rates more generous than those available in the federally regulated interstate wholesale market. ${ }^{84}$ Hughes cabined states' freedom to "compel[] participants in a federally regulated marketplace to transact capacity at prices other than the price fixed by [that] marketplace." 85 The Court, however, conspicuously withheld judgment on other methods for encouraging "new or clean generation, including tax incentives, land grants, direct subsidies, construction of state-owned generation facilities, or re-regulation of the energy sector. ${ }^{986}$ Environmental regulation and subsidies would compound the already difficult task of matching prices for electricity to the cost of generation, transmission, and distribution. ${ }^{87}$

The balance of Part II will treat the valuation of utility property as a variant of a pervasive financial problem: investment under uncertainty.

\section{B. A Generalized Model of Financial Uncertainty}

\section{Information Uncertainty}

Prices are signals. They communicate pivotal information about cost, supply, and demand within "the central nervous system of the economy." The discovery and dissemination of economic knowledge inform a collective "wisdom of prices." ${ }^{\prime \prime 9}$ What is true of prices on utility services is likewise true of the prices of those companies' shares, from individual trades ${ }^{90}$ to market-wide demand. ${ }^{91}$ Even while invalidating state-level efforts to spur construction of

83. 136 S. Ct. $1288(2016)$.

84. See id. at 1299. See generally Joel B. Eisen, Dual Electricity Federalism Is Dead, But How Dead, and What Replaces It?, 8 GEO. WASH. J. ENERGY \& ENVTL. L. 1, 19-20 (2017) (reviewing options available to states after Hughes).

85. PPL Energyplus, LLC v. Solomon, 766 F.3d 241, 255 (3d Cir. 2014).

86. Hughes, 136 S. Ct. at 1299; accord id. at 1300 (Sotomayor, J., concurring) ("recogniz[ing] the importance of protecting the States' ability to ... ensur[e] a sustainable supply of efficient and price-effective energy").

87. See Kevin M. Currier, Cost Reduction Incentives in Electricity Markets with Overlapping Regulations, 29 ELEC. J. 1 (2016); Kevin M. Currier, Incentives for Cost Reduction and Cost Padding in Electricity Markets with Overlapping "Green" Regulations, 38 UTIL. POL'Y 72 (2016).

88. United States v. Socony-Vacuum Oil Co., 310 U.S. 150, 225 n.59 (1940).

89. See, e.g., F.A. Hayek, Economics and Knowledge, 4 ECONOMICA 33 (1937); F.A. Hayek, The Use of Knowledge in Society, 35 AM. ECON. REV. 519 (1945); Richard Bronk, Hayek on the Wisdom of Prices: A Reassessment, 6 ERASMUS J. PHIL. \& ECON. 82 (2013); Sanford J. Grossman, Dynamic Asset Allocation and the Informational Efficiency of Markets, 50 J. FIN. 773 (1995)..

90. See, e.g., Michael J. Brennan \& Patricia J. Hughes, Stock Prices and the Supply of Information, 46 J. FIN. 1665 (1991); Joel Hasbrouck, Measuring the Information Content of Stock Trades, 46 J. FIN. 179 (1991); Joel Hasbrouck, The Summary Informativeness of Stock Trades: An Econometric Analysis, 4 REV. FIN. STUD. 571 (1991).

91. See, e.g., Myron S. Scholes, The Market for Securities: Substitution Versus Price Pressure and the Effects of Information on Share Price, 45 J. Bus. 179, 182 (1972) (describing how equilibrium among assets "of similar risk" calibrates "expected rates of return"); Andrei Shleifer, Do 
generating capacity, federal courts acknowledge that anticipated electrical sales revenue drive decisions to build (or retire) plants. ${ }^{92}$

The valuation of investor-owned utilities therefore demands the proper setting of utility rates. "[C]apital-intensive" utilities historically supported regulation so that they could "secure capital on favorable terms" rather than "rely[ing] . . o on long-term debt financing" to "finance new capital investment" that neither "the equity markets" nor "annual cash flow" would support, at least absent "guaranteed rates and protected franchises." 93 The price at which utilities can secure capital assumes greater importance in an industry that anticipates expensive low- and zero-carbon generation.

Finance is the branch of economics that analyzes the market for capital for speculative undertakings. ${ }^{94}$ An efficient capital market rewards the assumption of risk with returns. ${ }^{95}$ The expectation that the equity market's excess return over a risk-free asset "should vary positively and proportionately to market volatility" represents the "first law of finance." ${ }^{.96}$ As the Supreme Court has recognized: "The less risk, the less right to any unusual returns upon [an] investment[]." 97 Economic theory anticipates the fundamental problem of utility law: finding ways to "provide sufficient incentives for long-term investments in capacity."

"[E]very financial model" begins with "the uncertainty facing investors, and the substance of every financial model involves the impact of uncertainty on the behavior of investors and, ultimately, on market prices."99 Trouble arises in the zone of "[t]rue uncertainty," where "risks are not well understood, where the range of outcomes is potentially very large, and where probabilities cannot be assigned with confidence." 100 The distinction between quantifiable risk and wholly unknowable uncertainty, first recognized by Frank Knight and John

Demand Curves for Stocks Slope Down?, 41 J. FIN. 579 (1986); Aditya Kaul et al., Demand Curves for Stocks Do Slope Down: New Evidence from an Index Weights Adjustment, 55 J. FIN. 893 (2000).

92. See Hughes v. Talen Energy Mktg., LLC, 136 S. Ct. 1288, 1293 (2016) ("The capacity auction serves to identify need for new generation."); PPL Energyplus, LLC v. Solomon, 766 F.3d 241, 248 (3d Cir. 2014) (acknowledging that 15-year rate commitments "encourage[d] power generation companies ... to add a cumulative 2,000 megawatts of capacity").

93. Boyd, supra note 6 , at $1642-43$.

94. Cf. West v. Chesapeake \& Potomac Tel. Co., 295 U.S. 662, 689 (1935) (Stone, J., dissenting) (describing utility regulation as a "speculative undertaking" in its own right).

95. See, e.g., EugEne F. FAMA, Foundations of FinanCE 361 (1976); John Y. Campbell, Understanding Risk and Return, 104 J. POL. ECON. 298 (1996); Eugene F. Fama \& James D. MacBeth, Risk, Return and Equilibrium: Empirical Tests, 81 J. POL. ECON. 607, 624 (1973); Stephen Ross, The Arbitrage Theory of Capital Asset Pricing, 13 J. ECON. THEORY 341 (1976).

96. Evan W. Anderson, Eric Ghysels \& Jennifer L. Juergens, The Impact of Risk and Uncertainty on Expected Returns, 94 J. FIN. ECON. 233, 233 (2009); see also Robert C. Merton, On Estimating the Expected Return on the Market: An Exploratory Investigation, 8 J. FIN. ECON. 323, 324 (1980) (describing this specification of risk as 'a reasonable 'first approximation' theory for equilibrium expected returns").

97. Willcox v. Consol. Gas Co., 212 U.S. 19, 49 (1909).

98. Boyd, supra note 6 , at 1666 .

99. JOHN Y. CAMPBELL ET AL., THE ECONOMETRICS OF FINANCIAL MARKETS 3 (1997).

100. Daniel A. Farber, Uncertainty, 99 GEO. L.J. 901,906 (2011). 
Maynard Keynes, ${ }^{101}$ helps separate situations where "probabilities are available to guide choice" from situations where "information is too imprecise to be summarized by probabilities."102

Uncertainty affects all economic activity. ${ }^{103}$ Economic and political uncertainty suppresses investment. ${ }^{104}$ Political uncertainty motivates households to increase precautionary savings. ${ }^{105}$ Those savings fuel demand for government bonds and other safe assets. ${ }^{106}$ The vulnerability of developing countries to political uncertainty profoundly affects investments in infrastructure, ${ }^{107}$ as foreign investors" "fear of regulatory capture and opportunism" by the government reaches its apex. ${ }^{108}$ Consumers of public services, especially the most risk-averse, ${ }^{109}$ realize "option value" beyond conventional measures whenever uncertainty shrouds future demand. ${ }^{110}$

Capital markets fear uncertainty from "ambiguity with respect to the implications of new information for a firm's value." "11 Uncertainty exacts a

101. See FRANK KNIGHT, RISK, UNCERTAINTY, AND PROFIT 19-20 (1921) (distinguishing "risk" as "a quantity susceptible of measurement" from the "radically distinct" and "non-quantitative" concept of "uncertainty"); J.M. Keynes, The General Theory of Employment, 51 Q.J. ECON. 209, 213-14 (1937) ("About [certain matters there is no scientific basis on which to form any calculable probability whatever....").

102. Larry G. Epstein \& Tan Wang, Intertemporal Asset Pricing Under Knightian Uncertainty, 62 ECONOMETRICA 283, 283 (1994); accord Jochen Runde, Clarifying Frank Knight's Discussion of the Meaning of Risk and Uncertainty, 22 CAMBRIDGE J. ECON. 539, 539 (1998).

103. See, e.g., Rüdiger Bachmann et al., Uncertainty and Economic Activity: Evidence from Business Survey Data, 5 AM. ECON. J.: MACROECON. 217 (2013); Nicholas Bloom, The Impact of Uncertainty Shocks, 77 ECONOMETRICA 623 (2009).

104. See, e.g., Ben S. Bernanke, Irreversibility, Uncertainty and Cyclical Investment, 97 Q.J. ECON. 85 (1983); Benjamin Born \& Johannes Pfeifer, Policy Risk and the Business Cycle, 68 J. MONETARY ECON. 68 (2014); Jesús Fernández-Villaverde et al., Fiscal Volatility Shocks and Economic Activity, 105 AM. ECON. REV. 3352 (2015); Kevin A. Hassett \& Gilbert E. Metcalf, Investment with Uncertain Tax Policy: Does Random Tax Policy Discourage Investment?, 109 ECON. J. 372 (1999); cf. Brandon Julio \& Youngsuk Yook, Political Uncertainty and Corporate Investment Cycles, 67 J. FIN. 45 (2012) (finding that investment levels decline before national elections).

105. See Francesco Giavazzi \& Michael McMahon, Policy Uncertainty and Household Savings, 94 REV. ECON. \& STAT. 517 (2012).

106. See Luboš Pástor \& Pietro Veronesi, Political Uncertainty and Risk Premia, 110 J. FIN. ECON. 520 (2013); Luboš Pástor \& Pietro Veronesi, Uncertainty About Government Policy and Stock Prices, 67 J. FIN. 1219 (2012).

107. See, e.g., Babak Eftekhari \& Stephen E. Satchell, International Investors Exposure to Risk in Emerging Markets, 22 J. Fin. RESEARCH 83 (1999); Campbell R. Harvey \& Tadas Viskanta, Distributional Characteristics of Emerging Market Returns and Asset Allocation, 24:2 J. PORTFOlio MGMT. 102 (Winter 1998); Dani Rodrik, Policy Uncertainty and Private Investment in Developing Countries, 36 J. DEV. ECON. 229, 230-34 (1991).

108. GómEZ-IBÁÑEZ, supra note 35 , at 86-87.

109. See Charles J. Cicchetti \& A. Myrick Freeman III, Option Demand and Consumer Surplus: Further Comment, 85 Q.J. ECON. 528 (1971).

110. See Burton A. Weisbrod, Collective-Consumption Services of Individual Consumption Goods, 78 Q.J. ECON. 471 (1964).

111. X. Frank Zhang, Information Uncertainty and Stock Returns, 61 J. FIN. 105, 105

(2006). 
steeper toll on the downside. ${ }^{112}$ Economic retrenchment necessarily reduces the rate at which business activity transmits economic information. ${ }^{113}$

"[P] eople prefer to act on known rather than unknown or vague probabilities." "14 When informational "quality is difficult to judge, investors treat signals as ambiguous." 115 As informational ambiguity amplifies uncertainty over the probability and magnitude of default outcomes, including the deadweight cost of bankruptcy, all premiums associated with bearing risk rise sharply. ${ }^{116}$

Information uncertainty confounds valuable signals with noise:

Theoretically, an observed signal $(s)$ is characterized as a firm's fundamental value $(v)$, such as future cash flow or dividend, plus a noise term $(e)$, that is, $s=v+e$. The variance of this signal measures information uncertainty: $\operatorname{var}(s)=\operatorname{var}(v)+\operatorname{var}(e)$, where $\operatorname{var}(v)$ is a firm's underlying fundamental volatility and $\operatorname{var}(e)$ reflects the quality of information. ${ }^{117}$

This passage describes two formulas:

1. An economic signal (s) is the sum of value (v) and noise $(e): s=v+e$

2. The variance of that signal is the sum of the variance of value and the variance of noise. Equivalently, the variance of a signal consists of quantifiable risk plus a premium attributable to the reliability of information used to quantify risk: $\operatorname{var}(s)=\operatorname{var}(v)+\operatorname{var}(e)$

Both formulas find ready expression within rate regulation as an applied branch of financial economics. $s=v+e$ describes the utility's value as a function of economic fundamentals, such as anticipated cash flow from utility operations. $\operatorname{var}(s)=\operatorname{var}(v)+\operatorname{var}(e)$ indicates that variance in earnings comprises both fundamental variance and an additional premium reflecting uncertainty.

The reaction of investors to uncertainty deeply affects asset prices. "When agents are unsure of the correct probability laws governing the market return," "they demand a higher premium to hold the market portfolio."118 The following equation expresses the relationship between risk and uncertainty ${ }^{119}$ :

112. Cf. United States v. Butler, 297 U.S. 1, 82 (1936) (Stone, J., dissenting). ("Threat of loss, not hope of gain, is the essence of economic coercion.").

113. Nicholas Bloom, Fluctuations in Uncertainty, 28 J. ECON. PERSP. 153, 162 (2014); accord PABLO FAJGELBAUM ET AL., UNCERTAINTY TRAPS (2014); Stijn Van Nieuwerburgh \& Laura Veldkamp, Learning Asymmetries in Real Business Cycles, 53 J. MONETARY ECON. 753 (2006).

114. Epstein \& Wang, supra note 102, at 284.

115. Larry G. Epstein \& Martin Schneider, Ambiguity, Information Quality, and Asset Pricing, 43 J. FIN. 197, 197 (2008) (emphasis in original).

116. See Lawrence J. Christiano et al., Risk Shocks, 104 AM. ECON. REV. 27 (2014).

117. Zhang, supra note 111 , at 105 n.2

118. Anderson et al., supra note 96, at 234.

119. Id. 


$$
E_{t} r_{e, t+1}=\gamma V_{t}+\theta M_{t}
$$

where $E$ designates the expectation operator, $r_{e}$ is the excess return of the market over a risk-free asset, $V$ "is the conditional volatility of the market," $M$ "measures the amount of uncertainty in the economy," $t$ indexes all variables (and the expectation operator) over time, and coefficients $\gamma$ and $\theta$ indicate aversion to risk and uncertainty. ${ }^{120}$ Notably, this formula implies that "both risk and uncertainty carry a positive premium." ${ }^{21} E_{t} r_{e, t+1}=\gamma V_{t}+\theta M_{t}$ therefore represents a special case of $\operatorname{var}(s)=\operatorname{var}(v)+\operatorname{var}(e)$.

Bifurcating $s=v+e$ and $\operatorname{var}(s)=\operatorname{var}(v)+\operatorname{var}(e)$ will prove useful in evaluating economic signals whose underlying variability arises from distinct sources, one of which is less quantifiable and therefore more uncertain. Utilityowned infrastructure is rife with uncertainty. New electrical infrastructure designed to mitigate global climate change illustrates the impact of uncertainty on utility finance. Uncertainty along nearly every dimension scientific, technological, economic, and political — would raise the cost of capital for any private investment. The ability to express and measure distinct sources of risk and uncertainty, each with its own quantitative traits (including the impossibility of reliable quantification under current data and methods), will prove useful in evaluating the impact of rate regulation on utility valuation and access to capital.

\section{Risk-Neutrality and Irreversibility}

A project as ambitious as electrical de-carbonization also illustrates the interaction of uncertainty with asset-specificity and sunk costs. Kenneth Arrow's contributions to the risk-adjusted evaluation of public investments provide a useful starting point. ${ }^{122}$ Treating public ownership as the legal default sets a comparably neutral economic baseline. Municipal ownership accounts for onefifth of America's trillion-dollar electrical power industry ${ }^{123}$ and remains a viable alternative to private ownership. ${ }^{124}$

120. Id. at 233-34.

121. Id. at 234 .

122. See, e.g., Richard W. TREsch, Public FinANCE: A NORMATIVE THEORY 759-71 ( $2 \mathrm{~d}$ ed. 2002) (discussing uncertainty and the Arrow-Lind Theorem); Ziemowit Bednarek \& Marian Moszoro, The Arrow-Lind Theorem Revisited: Ownership Concentration and Valuation, 24 APPLIED FIN. ECON. 357 (2014); Eric Fesselmeyer et al., A Reconsideration of Arrow-Lind: Risk Aversion, Risk Sharing, and Agent Choice, 6 J. NAT. RESOURCES POL'Y RES. 51 (2014); L.P. Foldes \& R.A. Rees, A Note on the Arrow-Lind Theorem, 67 AM. ECON. REV. 188 (1977).

123. See BING ET AL., supra note 36 , at 14.

124. See Robert L. Bradley, Jr., The Origins and Development of Electric Power

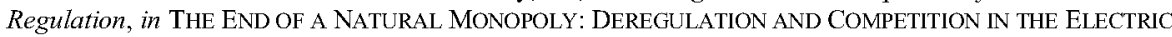
POWER INDUSTRY 43, 46-61 (Peter Z. Grossman \& Daniel H. Cole eds., 2003). 
Because "the risks associated with a public investment are publicly borne, the total cost of risk-bearing is insignificant." 125 Spreading "risk among all taxpayers" renders "negligible" the "costs of risk-bearing." 26 The resulting riskadjusted return may be higher than the private-sector equivalent, ${ }^{127}$ more so if risk aversion among shareholders or managers raises a private firm's cost of riskbearing. ${ }^{128}$ According to Arrow's 1970 work with Robert Lind, "the government should ignore uncertainty in evaluating public investments." 129

In terms of uncertainty within the variability of an economic signal, $\operatorname{var}(s)=\operatorname{var}(v)+\operatorname{var}(e)$, the public sector's unmatched ability to spread risk reduces risk-bearing cost and any uncertainty associated with that exercise in risk management - to zero. Variability in the signal collapses to variability in fundamental value: $\operatorname{var}(s)=\operatorname{var}(v)$. Even more significantly, expected return on public investment becomes the lone measure of value: $s=v .{ }^{130}$

Befitting an intellectual era that inspired intertemporal asset pricing ${ }^{131}$ and sustainability in resource economics, ${ }^{132}$ Arrow did not ignore intergenerational differences in "the revealed preference of individuals." 133 In 1974 work with Anthony Fisher, Arrow recognized limits on "the evaluation of benefits from more traditional public investments."134 Risk-neutrality collapses if public investment "involves some irreversible transformation of the environment [effecting] a loss in perpetuity ... and if information about the costs and benefits" changes future "expected values."135

Arrow and Fisher's exception to risk-neutrality finds strong legal parallels. The National Environmental Policy Act demands that environmental impact statements report "any irreversible and irretrievable commitments of resources." 136 The Endangered Species Act limits federal agencies" "irreversible

125. Kenneth J. Arrow \& Robert C. Lind, Uncertainty and the Evaluation of Public Investment Decisions, 60 AM. ECON. REV. 364, 366 (1970).

126. Id. at 374-75.

127. See id. at 374 ; cf. Jack Hirshleifer, Investment Decision Under Uncertainty: Applications of the State-Preference Approach, 80 Q.J. ECON. 262, 270 (1966) (suggesting that expected investment retum, without regard to risk-bearing costs, should provide the benchmark).

128. See Arrow \& Lind, supra note 125 , at 376.

129. Id. at 366 .

130. See id. at 374

131. See, e.g., Robert C. Merton, An Intertemporal Capital Asset Pricing Model, 41 ECONOMETRICA 867 (1973).

132. See, e.g., John M. Hartwick, Intergenerational Equity and the Investment of Rents from Exhaustible Resources, 67 AM. ECON. REV. 472 (1977); Robert M. Solow, The Economics of Resources or the Resources of Economics, 62 AM. ECON. REV. 1 (1974).

133. KenNeth J. ARrow \& Mordecal KurZ, Public investment, the Rate of RETURN, AND OPTIMAL FISCAL POLICY 12 (1970).

134. Kenneth J. Arrow \& Anthony C. Fisher, Environmental Preservation, Uncertainty, and Irreversibility, 88 Q.J. ECON. 312, 313 (1974).

135. Id. at $313-14$

136. 42 U.S.C. $\$ 4332$ (C)(v) (2018); see also 40 C.F.R. $\$ 1502.16$ (requiring consideration of the "irreversible and irretrievable commitment of resources" in an environmental impact statement's discussion of environmental consequences"). 
or irretrievable commitment of resources."137 Although Arrow and Fisher contemplated irreversible events such as "the extinction of a form of life, . . the destruction of a unique geomorphological phenomenon," or the introduction of nonbiodegradable stock pollutants, their observations "about uncertainty, information, and irreversibility" apply generally, "without reference to environmental effects." "138

Arrow and Fisher anticipated "cumulative 'macro' environmental effects, such as the increasing concentration of carbon dioxide in the global atmosphere, with its attendant climatic changes." 139 Pending ecological catastrophe invites even more aggressive applications of uncertainty. At the most extreme, the "dismal theorem" undermines all attempts at coherent forecasting. "[T]he expected loss from [extraordinary] risks such as climate change is infinite." "140 Under such extreme conditions, "standard economic analysis cannot be applied." 141 The "catastrophe-insurance aspect of ... a fat-tailed unlimited exposure-situation ... can dominate the social-discounting aspect, the pure-risk aspect, and the consumption-smoothing aspect." 142

Unlike the basic Arrow-Lind theorem, Arrow and Fisher's emphasis on irreversibility assigns maximum value to uncertainty. Within the basic specification of an economic signal's variability, $\operatorname{var}(s)=\operatorname{var}(v)+\operatorname{var}(e)$, these theoretical frames assume that $\operatorname{var}(e)$ is much greater than zero. At levels less apocalyptic than those characterizing the dismal theorem (which effectively assumes that $\operatorname{var}(e)$ approaches infinity), uncertainty may be modeled as the volatility of certain fundamental measures (such as growth in cash flow or dividends), conditioned on a time-varying measure of aversion. ${ }^{143}$ Markets with indeterminate variance ${ }^{144}$ are sometimes modeled according to stable

137. 16 U.S.C. $\S 1536$ (d) (2018); 50 C.F.R. $\$ 402.09$ (2017); see also, e.g., Conner v. Burford, 848 F.2d 1441, $1455 \mathrm{n} .34$ (9th Cir. 1988) ("Section 7(d) does not [mean] . . . that a biological opinion is not required before the initiation of agency action so long as there is no irreversible or irretrievable commitment of resources."); N. Slope Borough v. Andrus, 486 F. Supp. 332, 356 (D.D.C. 1980) (describing $\S 7(\mathrm{~d})$ as intended "to prevent Federal agencies from 'steam rolling' activity in order to secure completion of projects regardless of their impact on endangered species."), aff'd in part and rev'd in part on other grounds, 642 F.2d 589 (D.C. Cir. 1980).

138. Arrow \& Fisher, supra note 134 , at 319.

139. Id.

140. William D. Nordhaus, The Economics of Tail Events with an Application to Climate Change, 5 REV. ENVTL. ECON. \& POL'Y 240, 240 (2011).

141. Id.

142. Martin L. Weitzman, On Modeling and Interpreting the Economics of Catastrophic Climate Change, 91 REV. ECON. \& STAT. 1, 18 (2009); see also id. at 10-12 (specifying the dismal theorem in formal mathematical terms).

143. See, e.g., Geert Bekaert et al., Risk, Uncertainty, and Asset Prices, 91 J. FIN. ECON.

59 (2009).

144. See, e.g., BENOIT B. MANDELbRoIT, THE FRACTAL GEOMETRY OF NATURE 337-38 (1983); Eugene F. Fama, The Behavior of Stock-Market Prices, 38 J. BUS. 34, $43-45$ (1965); cf. Farber, supra note 100, at 923-24 n.95 (explaining why the law of large numbers does not "shrink down" the sample mean of a Cauchy distribution). 
distributions, ${ }^{145}$ despite their mathematical intractability and poor empirical fit. ${ }^{146}$ Using the variance risk premium ${ }^{147}$ as a proxy for uncertainty may explain risk factors known by names ${ }^{148}$ such as jump risk, ${ }^{149}$ tail risk, ${ }^{150}$ and rare disaster risk. $^{151}$

This account of uncertainty connects the environmental economics of irretrievably committed resources with sunk costs in microeconomics, the theory of contestable markets in industrial organization, and costly reversibility in finance. Pairing this narrative with expressions for individual components of economic signals and for variability in those signals provides a generalized framework for evaluating regulatory uncertainty. Especially for industries such as a future zero-carbon electrical system, these insights portend "a relatively high cost of capital" and "very challenging" financial issues for industries facing "large, capital-intensive" investments, "long time horizons" and "uncertainty regarding performance, future prices, and regulations." "52 To ground those potentially grave implications in legal principles, I now discuss the regulatory determination of return on utility assets.

\section{Conventional Rate of Return Determinations}

\section{A. Cost-of-Service Ratemaking}

The task of price regulation at "the heart of public utility regulation" has drawn deep scorn. ${ }^{153}$ "The Supreme Power who conceived gravity, supply and demand, and the double helix must have been absorbed elsewhere when public utility regulation was invented." 54 Rate regulation has earned opprobrium as

145. See, e.g., S. Ortobelli L \& S.T. Rachev, Safety-First Analysis and Stable Paretian Approach to Portfolio Choice Theory, 34 MATH. \& COMPUTER MODELING 1037 (2001).

146. See CAMPBELL, LO \& MACKINLAY, supra note 99, at 18; James A. Xiong \& Thomas M. Idzorek, The Impact of Skewness and Fat Tails on the Asset Allocation Decision, FIN. ANALYSTS J., March/April 2011, at 23, 24.

147. See Turan G. Bali \& Hao Zhou, Risk, Uncertainty, and Expected Returns, $51 \mathrm{~J}$ FIN. \& QUANT. ANALYSIS 707, 708 (2016) (defining the variance risk premium as the difference between realized variance and the variance swap rate); Peter Carr \& Liuren Wu, Variance Risk Premiums, 22 REV. FIN. STUD. 1311 (2009); George J. Jiang \& Yisong S. Tian, Model-Free Implied Volatility and Its Information Content, 18 REV. FIN. STUD. 1305 (2005).

148. See Bali \& Zhou, supra note 147 , at $709-10$ n.4.

149. See Itamar Drechsler \& Amir Yaron, What's Volatility Got to Do with It?, 24 REV. FIN. STUD. 1 (2011); Viktor Todorov, Variance Risk Premium Dynamics: The Role of Jumps, 23 REV. FIN. STUD. 345 (2010).

150. See Tim Bollerslev \& Viktor Todorov, Tails, Fears, and Risk Premia, 66 J. FIN. 2165 (2011); Bryan Kelly \& Hao Jiang, Tail Risk and Asset Prices, 80 ECONOMETRICA 559 (2012).

151. See Xavier Gabaix, Variable Rare Disasters: An Exactly Solved Framework for Ten Puzzles in Macro-Finance, 127 Q.J. ECON. 645 (2012).

152. Boyd, supra note 6, at 1689-90.

153. 1 AlFRED KahN, The ECONOMICS OF REgulation: PRINCIPLES AND INSTITUTIONS

20 (1988).

154. F.M. SCHERER, Industrial MARKET STRUCTURE AND ECONOMIC PERFormanCE 537 (1st ed. 1970); accord GERALD W. BROCK, TELECOMMUNICATION POLICY FOR THE INFORMATION AGE 
"the most speculative undertaking $\ldots$ in the history of [Anglo-American] jurisprudence." 155

But ratemaking is neither lawless nor incoherent. Although courts today do not bind ratemaking agencies to "any single formula or combination of formulae," 156 stable patterns have emerged. Admittedly, neither the Fourteenth Amendment nor the statutory "just and reasonable" ratemaking standard has enacted discounted cash flow analysis, the efficient market hypothesis, or capital asset pricing. ${ }^{157}$ Those are the terms, however, by which rate regulation has priced utility services and shaped demand for utility stock.

Ratemaking traces its roots to the Supreme Court's 1898 decision in Smyth v. Ames. ${ }^{158}$ Smyth is simultaneously celebrated and derided for its declaration that "the basis of all calculations as to the reasonableness of ... rates to be charged by a [public utility] must be the fair value of the property being used by it for the convenience of the public." ${ }^{59}$ To clarify this baffling formula, the Court offered a list of factors: "the original cost of construction, the amount expended in permanent improvements, the amount and market value of [utility] bonds and stock, the present as compared with the original cost of construction, the probable earning capacity of the property ... and the sum required to meet operating expenses." 160

Smyth prescribed rates according to "the cost of providing the service" rather than "some other basis," especially "demand for the service."161 In defending a competing definition of cost as the historic sum of prudent investments, Justice Brandeis restated Smyth as encompassing "not only operating expenses, but also capital changes" covering "interest, for the use of the capital; ... [an] allowance for risk incurred; and enough more to attract capital." 162 Any rate that gives the utility "the opportunity to earn the cost of . . . service" should be deemed "constitutionally compensatory."163

20 (1994); Stuart Buck, TELRIC vs. Universal Service: A Takings Violation?, 56 FED. COMM. L.J. 1, 8 (2003).

155. West v. Chesapeake \& Potomac Tel. Co., 295 U.S. 662, 689 (1935) (Stone, J., dissenting).

156. Fed. Power Comm'n v. Hope Nat. Gas Co., 320 U.S. 591, 602 (1944).

157. Tenn. Gas Pipeline Co. v. FERC, 926 F.2d 1206, 1211 (D.C. Cir. 1991); cf. Lochner v. New York, 198 U.S. 45, 75 (1905) (Holmes, J., dissenting) ("The Fourteenth Amendment does not enact Mr. Herbert Spencer's Social Statics.").

158. 169 U.S. $466(1898)$

159. Smyth, 169 U.S. at 546; accord Willcox v. Consol. Gas Co., 212 U.S. $19,41(1909)$

("There must be a fair return upon the reasonable value of the property at the time it is being used for the public."); Minn. Rate Cases, 230 U.S. 352, 434 (1913) (describing fair value as "a reasonable judgment having its basis in a proper consideration of all relevant facts.")

160. Smyth, 169 U.S. at 546-47.

161. LOUIS SCHWARTZ ET AL., FreE ENTERPRISE AND ECONOMIC ORGANIZATION GOVERNMENT REGULATION 369 (6th ed. 1985).

162. Mo. ex rel. Sw. Bell Tel. Co. v. Pub. Serv. Comm'n, 262 U.S. 276, 291 (1923) (Brandeis, J., dissenting). 163. $I d$ 
Subsequent "methodology for establishing the cost of providing [utility] service" followed "a formula implicit in the Smyth opinion".: 64

$$
R R=r \cdot B+O C+T
$$

where

\author{
$R R$ : revenue requirement \\ $R$ : rate of return \\ $B$ : rate base \\ $O C$ : operating costs \\ $T:$ taxes
}

Although all of these variables spark ratemaking disputes, ${ }^{165}$ the "cost of common equity is frequently ... a point of contention." elements of a regulated firm's cost of capital (long-term debt, preferred stock, and common stock), ${ }^{167}$ the rate of return on equity is often most fiercely contested, not least because that factor dictates market capitalization. Return on equity must be "sufficient to assure confidence in the financial integrity of the enterprise."168 Focusing on theoretical implications for regulatory economics, Part III now evaluates judicial standards for determining the cost of equity.

Smyth's fair value standard faltered in practice. "In theory the . . fair value standard mimics the operation of the competitive market," inasmuch as "investments [whose] benefits exceed their costs ... reward [utilities] with an

164. SCHWARTZ ET AL., supra note 161, at 369; see, e.g., Williston Basin Interstate Pipeline Co. v. FERC, 165 F.3d 54, 56-57 (D.C. Cir. 1999); RiCHARD E. MATHENy, TAXATION OF PubliC UTILITIES \$ 2.04 (2014); Darin W. Kempke, Regulated Utilities, in 2 ACCOUNTANTS HANDBOOK: SPEClAL INDUSTRIES AND SPECIAL TOPICS, at 36-6 to 36-11 (D.R. Carmichael \& Lynford Graham eds., 12th ed. 2012).

165. See, e.g., Exxon Corp. v. FERC, 114 F.3d 1252, 1263 (D.C. Cir. 1997) (disputing the use of cost data after a utility's test period, see 18 C.F.R. $\$ 154.303$ (a)(4)); Boston Edison Co. v. FERC, 885 F.2d 962, 964 (1st Cir. 1989) (contesting the rate base).

166. Williston Basin Interstate Pipeline Co. v. FERC, 164 F.3d 54, 57 (D.C. Cir. 1999); see Tenn. Gas Pipeline Co. v. FERC, 926 F.2d 1206, 1208 (D.C. Cir. 1991); NEPCO Munic. Rate Comm. v. FERC, 668 F.2d 1327, 1335 (D.C. Cir. 1981).

167. See N.C. Utils. Comm'n v. FERC, 42 F.3d 659, 661 (D.C. Cir. 1994); New England Tel. \& Tel. Co.v. Pub. Utils. Comm'n, 390 A.2d 8, 32 (Me. 1978). Regulators often invoke "double leverage" to limit returns attributable to a utility holding company's lower cost of debt. See, e.g., Sw. Bell Tel. Co. v. Ark. Pub. Serv. Comm'n, 593 S.W.2d 434, 444 (1980); New England, 390 A.2d at 41; State v. Pub. Serv. Comm'n, 706 S.W.2d 870, 876 (Mo. Ct. App. 1985). See generally Richard H. Pettway \& Bradford D. Jordon, Diversification, Double Leverage, and the Cost of Capital, 6 J. FIN. RESEARCH 289 (1983); Michael S. Rozeff, Modified Double Leverage-A New Approach, PUB. UtiLs. ForTNIGHTLY, March 31, 1983, at 31-36.

168. Fed. Power Comm'n v. Hope Nat. Gas Co., 320 U.S. 591, 603 (1944); accord, e.g., United States v. FCC, 707 F.2d 610, 612 (D.C. Cir. 1983). 
opportunity to earn an 'above-cost' return."169 Fair value demanded consideration of prevailing prices and wages, as well as "an honest and intelligent forecast as to probable price and wage levels during ... the immediate future." $" 70$ At its most speculative, fair value emboldened a prediction, based on "judicial notice of the fact that there ha[d] been no substantial general decline in the price of labor and materials" for roughly a dozen years, that prices would not be "likely to decline within ... one, two, or three years."171 Within three years of this November 22, 1926, declaration, the stock market crash of October 1929 triggered the Great Depression.

As the Supreme Court later observed with respect to taxation, "the Constitution [does not] tolerate any result, however distorted, just because it is the product of a convenient mathematical formula." 172 Practical difficulties plagued the valuation of property whose owners bore legal obligations unique to their industry. ${ }^{173}$ Justice Brandeis defended his "prudent investment" rule as an administratively convenient alternative to the "laborious and baffling task of finding ... present value" for utilities "not commonly bought and sold in the market." 174

Commentators likewise condemned Smyth as "rest[ing] upon a giant illusion." 175 Even courts recognizing that "value depends upon the earnings" foolishly "insist[ed] that the vicious circle involved (in basing the earnings on the value) can be escaped merely by the simple expedient of measuring the value of replacement cost." "176 The entire enterprise, which Smyth called an "embarrassing question," with the Law of Nature and the Social Contract." 178 By 1944, the Supreme Court capitulated: "rates cannot be made to depend upon 'fair value' when the value of the going enterprise depends on earnings under whatever rates may be anticipated." 179

169. Duquesne Light Co. v. Barasch, 488 U.S. 299, 308 (1989).

170. McCardle v. Indianapolis Water Co., 272 U.S. 400, 408 (1926).

171. Id. at 412

172. Norfolk \& W. Ry. Co.v. Mo. State Tax Comm’n, 390 U.S. 317, 327 (1968); cf. CSX Transp., Inc. v. Georgia State Bd. of Equalization, 552 U.S. 9, 16-17 (2007) ("Valuation is not a matter of mathematics, as if ... [a] court could prevent discriminatory taxation simply by double-checking ... assessment equations.").

173. See Duquesne, 488 U.S. at 309.

174. Mo. ex rel. Sw. Bell Tel. Co. v. Pub. Serv. Comm'n, 262 U.S. 276,292 (1923) (Brandeis, J., dissenting) ("Nor can the present value of the utility be determined by capitalizing its net earnings, since the earnings are determined ... by the rate which the company will be permitted to charge ...").

175. Gerard Henderson, Railway Valuation and the Courts (Part 3), 33 HaRV. L. REV. $1031,1051(1920)$.

176. Robert Lee Hale, The "Physical Value" Fallacy in Rate Cases, 30 YALE L.J. 710,

$716(1921)$

177. Smyth v. Ames, 169 U.S. 466, 546 (1898).

178. Henderson, supra note 175 , at 1051.

179. Hope Nat. Gas Co.v. Fed. Power Comm'n, 320 U.S. 591, 601 (1944); accord Robert Lee Hale, Utility Regulation in Light of the Hope Natural Gas Case, 44 CoLUM. L. REV. 488, 496 (1944) 


\section{B. Bluefield's Two Standards}

But three weeks after Justice Brandeis proposed prudent investment as an alternative to Smyth's fair value standard, the Supreme Court provided further guidance on determining the rate of return, ${ }^{180}$ which remains good law, notwithstanding the Court's later embrace of prudent investment as a permissible (but not required) basis for valuation. ${ }^{181}$

Bluefield prescribed not one but two sets of guidelines. The first, the "comparable investment" rule, promised "such rates as will permit" the utility "to earn a return ... equal to that generally being made at the same time and in the same general part of the country on investments in other business undertakings which are attended by corresponding, risks and uncertainties," but not the return "anticipated in highly profitable enterprises or speculative ventures." $" 182$

Bluefield"s second approach prescribes rates "reasonably sufficient to assure confidence in the financial soundness of the utility" and "adequate . . . to maintain and support its credit and enable it to raise the money necessary for the proper discharge of its public duties." ${ }^{.183}$ Utilities must earn returns sufficient to "attract capital" and "compensate investors for the risks assumed." ${ }^{184}$ Rates that "compensate[] investors" and "attract capital" should cover "operating expenses, debt service, and dividends." 185

Three years before the Supreme Court directly addressed the issue, Learned Hand anticipated the congruence of Bluefield"s two standards. "The recurrent appeal to a just rate and a fair value," he wrote, "involves a tacit comparison of the profit under the rate with profits available elsewhere; i.e., under those competitive enterprises which offer an alternative investment."186 Judge Hand's

(praising the Court's "tardy but conclusive demonstration of the fair value fallacy"); id. at 530 (dismissing "the costly and meaningless rituals of Smyth v. Ames.").

180. Bluefield Water Works \& Improvement Co. v. Pub. Serv. Comm'n, 262 U.S. 679 (1923). Missouri ex rel. Southwestern Bell Tel. Co. v. Public Serv. Comm'n, 262 U.S. 276 (1923), was argued December 8, 1922, and decided May 21, 1923. Argued on January 22, 1923, Bluefield was decided June 11, 1923, 21 days after Southwestern Bell.

181. See Duquesne Light Co.v. Barasch, 488 U.S. 299, 316 \& n.10 (1989); $c f$. Fed. Power Comm'n v. Texaco, Inc., 417 U.S. 380, 387 (1974) ("The [Natural Gas] Act directs that all producer rates be just and reasonable, but it does not specify the means by which that regulatory prescription is to be fulfilled."); Hope, 320 U.S. at 602 ("It is not theory, but the impact of the rate order which counts. If the total effect of the rate order cannot be said to be unjust and unreasonable, judicial inquiry . . is at an end.").

182. Bluefield, 262 U.S. at $692-93$.

183. Id. at 693 .

184. Hope, 320 U.S. at 605; accord A. LAWREnCE KOLBE ET AL., THE COST OF CAPITAL: ESTIMATING THE RATE OF RETURN FOR PUBLIC UTILITIES 13 (1984) ("The cost of capital is the minimum rate of return necessary to attract capital to an investment.").

185. Mass. Elec. Co. v. Dep't of Pub. Utils., 389 N.E.2d 325, 328 (Mass. 1978); accord State v. Public Serv. Comm'n, 706 S.W.2d 870, 875 (Mo. Ct. App. 1985); see also United States v. FCC, 707 F.2d 610,612 (D.C. Cir. 1983) ("Regulated utilities are entitled to earn enough revenue not only to cover operating expenses but also to pay for the capital costs of doing business, including service on debt and dividends on stock.").

186. Consol. Gas Co. v. Newton, 267 F. 231, 236 (S.D.N.Y. 1920). 
"statement of the comparable-earnings standard" recognized that "attracting capital" requires offsetting the opportunity cost of alternative investments. ${ }^{187}$

Judge Hand and Bluefield reflected the modern understanding of opportunity cost as "the cost associated with opportunities that are forgone by not putting [a] firm's resources to their best alternative use." ${ }^{\prime 188}$ Opportunity cost offsets the behavioral impact of sunk cost. ${ }^{189}$ Whereas sunk cost is "usually visible" but "should always be ignored," opportunity cost "is often hidden" but must always "be taken into account." 190 Irrational consideration of sunk costs often prompts conduct based on previous investment. ${ }^{191}$ Agents are sometimes "too much invested to quit." 192 Regulatory accounting should not compound such irrationality.

Bluefield"s "two conceptions are obviously intertwined."193 Proper understanding of the regulatory rate of return begins more intuitively with a firmspecific focus on the conditions that would induce investors to bypass other options. Justice Brandeis recognized that a continuous "inflow of [new] capital" into a regulated firm "can only be assured by treatment of capital already invested," so that fairness toward existing investors "will invite and encourage further investment." 194

Bluefield's two standards coexist today alongside a model derived from corporate finance. Parts IV and V will examine all three models.

187. Harold Leventhal, Vitality of the Comparable Earnings Standard for Regulation of Utilities in a Growth Economy, 74 YALE L.J. 989, 1004 (1965).

188. PINDYCK \& RUBINFELD, supra note $52, \S 7.1$, at 238 ; see also id. $\S 15.4$, at 584 (defining the opportunity cost of capital).

189. See Shane Frederick et al., Opportunity Cost Neglect, 36 J. CONSUMER RESEARCH $553(2009)$.

190. PINDYCK \& RUBINFELD, supra note 52, § 7.1, at 239; accord, e.g., Stephen Palmer \& James Rafferty, Opportunity Cost, 318 BRITISH MED. J. 1551 (1999).

191. See Hal R. Arkes \& Catherine Blumer, The Psychology of Sunk Costs, 35 ORG. BeHAV. \& HuMAN DECISION PROCESSES 124 (1985); cf. Hal R. Arkes \& Peter Ayton, The Sunk Cost and Concorde Effects: Are Humans Less Rational Than Lower Animals, 125 PSYCH. BULL. 591, 591 (1999) (describing "the tendency of lower animals to commit to the sunk cost effect" and citing Richard Dawkins \& Tamsin R. Carlisle, Parental Investment, Mate Desertion and a Fallacy, 262 NATURE 131 (1976); Robert L. Trivers, Parent-Offspring Conflict, 14 AM. ZOOLOGIST 249 (1974))

192. ALLAN I. TEGER, TOO MUCH INVESTED TO QUIT (1980).

193. Leventhal, supra note 187 , at 1004 .

194. St. Louis \& O'Fallion Ry. v. United States, 279 U.S. 461, 502 (1929) (Brandeis, J.,

dissenting). 


\section{Regulatory Asset Pricing After Bluefield}

\section{A. Attracting Capital}

\section{Discounted Cash Flow}

A 1991 D.C. Circuit case, Tennessee Gas Pipeline Co. v. FERC, ${ }^{195}$ illustrates pitfalls in determining a return sufficient to attract capital. In setting gas pipeline rates under section 4 of the Natural Gas Act, ${ }^{196}$ FERC reasoned "that investors are not able to account fully for the effects of a decline in interest rates on their investment alternatives until some six months or more after those rates are published." 197 That assertion invited withering scrutiny of FERC's discounted cash flow (DCF) methodology.

"DCF analysis" assumes "that the price of a stock is the current value of all expected future cashflows, discounted at the rate of return." ${ }^{198} \mathrm{DCF}$ assumes that the price of stock equals the present value of a company's dividend stream, projected to grow at a constant rate: ${ }^{199}$

$$
P_{0}=\frac{D_{1}}{r-g}
$$

where

$$
\begin{aligned}
& P_{0}: \text { Today's price } \\
& D_{1}: \text { Next year's dividend } \\
& r: \text { Rate of return } \\
& g: \text { Rate of growth }
\end{aligned}
$$

Solving for $r$, the rate of growth, yields $r=D_{1} / P_{0}+g$. That "key equation ... employs the current price of the utility, because price is understood to represent the best possible assessment of . . . available information." 200

Discounted cash flow analysis enjoys a prominent role in utility economics. $^{201}$ In 1966, Lionel Thatcher proposed that the Federal

195. 926 F.2d 1206 (D.C. Cir. 1991).

196. 15 U.S.C. $\$ 717 \mathrm{c}(2018)$.

197. Tenn. Gas Pipeline Co. v. FERC, 926 F.2d 1206, 1209 (D.C. Cir. 1991).

198. Id. at 1210

199. See, e.g., KOLBE ET AL., supra note 184, at 54; ROGER A. MORIN, UTILITIES' COST OF CAPITAL 82, 119-20 (1984).

200. Tenn. Gas, 926 F.2d at 1210.

201. See, e.g., General Tel. Co. v. Iowa State Commerce Comm'n, 275 N.W.2d 364, 369 (Iowa 1979); New England Tel. \& Tel. Co. v. Pub. Utils. Comm'n, 390 A.2d 8, 36 (Me. 1978). 
Communications Commission adopt an earnings-price model identical to the DCF model in Tennessee Gas. ${ }^{202}$ Because the simple ratio of earnings to price allegedly "understate[d] true capital costs by failing to account for investor expectations of future growth," Thatcher proposed "a 'growth factor' determined by the ratio of dividends to the book value of stock adjusted for growth."203

In his final scholarly work before being appointed to the D.C. Circuit, Harold Leventhal recognized that "it is mathematically sound"-albeit with "simplifying assumptions"-_"to express the capital attracting rate for equity as equal to ... [the] dividend-price ratio ... plus the anticipated growth rate in earnings per share." ${ }^{204} r=D_{1} / P_{0}+g$ "is a tautology," Leventhal admitted. ${ }^{205}$ "[B]ut it is a correct tautology."206

\section{Gordon Growth Model}

The Gordon growth model describes stock prices as a function of dividends and dividend growth rates: ${ }^{207}$

$$
P=\frac{D(1+g)}{r+\pi-g}
$$

where $r$ is the risk-free rate, $P$ is the stock price, $D$ is the current dividend, $g$ is the expected rate of dividend growth and $\pi$ is the equity risk premium. ${ }^{208}$ The Gordon growth model holds even when interest rates, growth rates, and the risk premium change, ${ }^{209}$ provided that "the long-run growth rate, $g$, is ... interpreted as a weighted average of expected future growth rates." ${ }^{210}$ Holding the equity risk premium to zero and redefining $D(1+g)$ as a forward-looking dividend-D(1+g) $=D_{1}$-reveals the DCF formula in Tennessee Gas as a special case of the Gordon growth model:

$$
P=\frac{D(1+g)}{r+\pi-g} \leftrightarrow P_{0}=\frac{D_{1}}{r-g} \because \pi=0, D_{1}=D(1+g)
$$

202. See Robert J. Gelhaus \& Gary D. Wilson, Note, An Earnings-Price Approach to Fair Rate of Return in Regulated Industries, 20 STAN. L. REV. 287, 290 \& n.9 (1968).

203. Id. at 290 .

204. Leventhal, supra note 187 , at 1009

205. Id. at 1009 n. 72 .

206. Id.

207. See Myron J. Gordon \& Eli Shapiro, Capital Equipment Analysis: The Required Rate of Profits, 3 MGMT. SCI. 102 (1956); Myron J. Gordon, Dividends, Earnings and Stock Prices, 41 REV. ECON. \& STAT. 99 (1959).

208. See John H. Boyd et al., The Stock Market's Reaction to Unemployment News: Why Bad News Is Usually Good for Stocks, 60 J. FIN. 649, 660 (2005).

209. See Ravi Jagannathan et al., The Declining U.S. Equity Premium, FED. RESERvE BANK MINNEAPOLIS Q. REV., Fall 2000, at 3.

210. See Boyd et al., supra note 208 , at 660 . 
Further simplification may be achieved by holding dividend growth to zero. In that event, the rate of return is simply the ratio of forward-looking dividends to current stock price: ${ }^{211}$

$$
r=\frac{D_{1}}{P_{0}} \because P_{0}=\frac{D_{1}}{r}
$$

The simple ratio of earnings to stock price "generat[es] that level of earnings necessary to maintain the share price at the attributed rate base per share," where investors will buy utility stock. ${ }^{212}$ Among other criticisms of a straightforward calculation of the "going rate of return ... directly from the market evaluation of . . utility stock," $" 213$ is the allegation that the earnings-price ratio "is particularly inapplicable to a new venture, whose observed stock price reflects anticipated rather than current earnings." 214 Simple implementations of the Gordon growth model may not capture all macroeconomic factors affecting stock prices and firm valuations. ${ }^{215}$

Its very simplicity, however, enables the Gordon growth model to accommodate numerous assumptions. Many authors "extend the simplest Gordon growth model to allow dividend growth rates to have several stages."216 Some models "permit[] growth firms to start with high dividend growth rates and then decelerate to a stable long-run rate." 217 Others "propose random but independent dividend growth rates." 18 One "variant of the Gordon growth model ... us[es] the assumption that the $\log$ dividend price ratio follows a random walk" - $D_{t+1} / P_{t}=\exp \left(x_{t}\right)$, where $x_{t}=x_{t+1}+\varepsilon_{t}$ "denotes the log dividend-price ratio using a forward or indicated dividend rather than a historical dividend." 219

211. See, e.g., William J. Bernstein, The InTElligent AsSEt Allocator: How tO BUILD YOUR PORTFOLIO TO MAXIMIZE RETURNS AND MINIMIZE RISK 112-13, 192 (2001) (defining priceto-earnings and price-to-book ratios).

212. Gelhaus \& Wilson, supra note 202, at 295

213. Leonard M. Ross, Comments on the Earnings-Price Note, 21 STAN. L. REV. 644, 644 (1969); see also Posner, supra note 46, at 625-27.

214. Ross, supra note 213 , at 645.

215. See, e.g., Marcus Jackson, The Gordon Growth Model and the Income Approach to Value, 62 Appraisal J. 124 (1994); Michael T. Kiley, Stock Prices and Fundamentals: A Macroeconomic Perspective, 77 J. BuS. 909 (2004) (comparing the Gordon growth model during the 1990s disfavorably with dynamic general equilibrium models over that period).

216. Mark Kamstra, Pricing Firms on the Basis of Fundamentals, ECON REv. FED. RESERVE BANK ATLANTA, 1st Quarter 2013, at 49, 50. Accord, e.g., James L. Farrell, Jr., The Dividend Discount Model: A Primer, FIN. ANALYSTS J., Nov./Dec. 1985, at 16; William J. Hurley \& Lewis D. Johnson, A Realistic Dividend Valuation Model, FIN. ANALYSTS J., July/Aug. 1994, at 50; James A. Ohlson, Earnings, Book Values, and Dividends in Equity Valuation, 11 CONTEMP. ACCOUNTING RESEARCH 661 (1995); Eric $\mathrm{H}$. Sorenson \& David A. Williamson, Some Evidence on the Value of Dividend Discount Models, FIN. ANALYSTS J., Nov.Dec. 1985, at 60.

217. Kamstra, supra note 216 , at 50 .

218. Id.

219. John Y. Campbell, Estimating the Equity Premium, 41 CAN. J. ECON. 1, 10 (2008). 
Tennessee Gas represented a stark departure from established principles of discounted cash flow analysis and other dividend growth models. FERC's effort to defend "a "pragmatic adjustment"" on the basis of an alleged "lag in the decline of dividend yields following [a] decline in interest rates" raised an "intolerable conflict with [DCF] principles."220 "Everything else being equal, a decline in interest rates means a decline in dividend yields, as stocks and bonds compete for investors' capital. ${ }^{221}$ Declining rates drive capital from bonds into stocks, causing the price of utility stock to rise and its yield to drop. ${ }^{222}$ Even sources cited by FERC identified utility stocks "as especially close substitutes of bonds" in light of "their (historically) low levels of risk" and similar sensitivity to interest rates. $^{223}$

\section{Efficient Market Hypothesis}

Even more importantly, FERC's handling of interest-rate evidence, especially its "lag theory" of delayed investor reactions to interest-rate changes, constituted "a frontal assault on 'the cornerstone of modern investment theory,' the Efficient Market Hypothesis." 224 The "strong" form of the efficient market hypothesis posits that security prices reflect all information, public and private, and that the prevalence of this knowledge prevents investors from earning excess returns. ${ }^{225}$ " $[\mathrm{I}] \mathrm{n}$ an efficient market, there is no way for most investors to achieve consistently superior rates of return."226 Empirical measures of investment

220. Tenn. Gas Pipeline Co. v. FERC, 926 F.2d 1206, 1209-10 (D.C. Cir. 1991); see also Martin Lettau \& Sydney Ludvigson, Consumption, Aggregate Wealth, and Expected Stock Returns, $56 \mathrm{~J}$. FIN. 815, 819 (2001) (proposing "a 'Gordon growth model' for human capital by assuming that expected returns to human capital are constant and labor income follows a random walk"). For firms too new or speculative to have reliable dividend information, models use alternatives to dividends. See, e.g., ASWATH DAMODARAN, DAMODARAN ON VALUATION: SECURITY ANALYSIS FOR INVESTMENT AND CORPORATE FINANCE 244-48 (1994) (sales); WILLIAM F. SHARPE \& GORDON J. ALEXANDER, INVESTMENTS 474-76 (4th ed. 1990) (earnings and payout ratios).

221. Tenn. Gas, 926 F.2d at 1209 .

222. Id.; accord MORIN, supra note 199 , at 30 .

223. Tenn. Gas, 926 F.2d at 1211 (citing JEROME BERNARD COHEN ET AL., INVESTMENT ANALYSIS AND PORTFOLIO MANAGEMENT 27-28 (5th ed. 1987)); see, e.g., K. Chen \& Daniel Tzang, InterestRate Sensitivity of Real Estate Investment Trusts, $3: 3$ J. REAL ESTATE RES. 13 (1988); Mark J. Flannery \& Christopher M. James, The Effect of Interest Rate Changes on the Common Stock Returns of Financial Institutions, 39 J. FIN. 1141 (1984); Glenn Mueller \& Keith Pauley, The Effect of Interest-Rate Movements on Real Estate Investment Trusts, 10 J. REAL ESTATE RES. 319 (1995); Richard J. Sweeney \& Arthur D. Warga, The Pricing of Interest-Rate Risk: Evidence from the Stock Market, 41 J. FIN. 393 (1986).

224. Tenn. Gas, 926 F.2d at 1211 (quoting MORIN, supra note 199, at 140 n.4).

225. See, e.g., Eugene F. Fama, Efficient Capital Markets: A Review of Theory and Empirical Work, 25 J. FIN. 383 (1970); Eugene F. Fama, Efficient Capital Markets II, 46 J. FIN. 1575 (1991); Eugene F. Fama, The Behavior of Stock Market Prices, 38 J. Bus. 34 (1965); Lawrence H. Summers, Does the Stock Market Rationally Reflect Fundamental Values?, 41 J. FIN. 591 (1986); Eugene F. Fama \& Kenneth R. French, The Cross-Section of Expected Stock Returns, 47 J. FIN. 427, 427-29 (1992).

226. Richard A. BREALEY ET AL., PRINCIPLES OF CORPORATE FINANCE 330 (10th ed 2011); accord Amgen Inc. v. Conn. Ret. Plans \& Trust Funds, 568 U.S. 455, 462 (2013); see also Tenn. Gas, 926 F.2d at 1211 ("[I]f the stock market is such a laggard, the members of the Commission ... would do well to abandon their regulatory work and turn to exploitation of their theory [through arbitrage]."). 
outcomes suggest that efficient markets, even if not omniscient or frictionless, do eliminate excess returns, at least with respect to individual securities or other small samples. $^{227}$

Even less stringent versions of the efficient market hypothesis bode ill for excess returns. ${ }^{228}$ The weak version posits that markets assimilate all public information. ${ }^{229}$ The semi-strong version assumes immediate diffusion of public information into security prices. ${ }^{230}$ Acceptance of the efficient market hypothesis in weak form eliminates excess returns from technical analysis. ${ }^{231}$ The semistrong version defeats fundamental analysis. ${ }^{232}$ Disproving the presence of serial dependencies in security prices would confirm at least the weak hypothesis. ${ }^{233}$ By citing evidence that markets assimilated surprising news regarding the discount rate, money supply, inflation, and real economic activity within one day, Tennessee Gas acknowledged at least the weak form of the hypothesis. ${ }^{234}$

The law of regulated industries is likely to follow federal securities law. The "fraud on the market" rule presumes that "the market price of shares traded on well-developed markets reflects all publicly available information and, hence, any material misrepresentations," and that the typical investor who trades at market price relies "on the integrity of that price."235 In adopting the "fraud on the market" theory, the Supreme Court has "relied upon the 'semi-strong' version" of the efficient market hypothesis. ${ }^{236}$

227. See Eugene F. Fama \& Kenneth R. French, Luck Versus Skill in the Cross-Section of Mutual Fund Returns, 65 J. FiN. 1915 (2010).

228. See Frederick C. Dunbar \& Dana Heller, Fraud on the Market Meets Behavioral Finance, 31 DEL. J. CORP. L. 455, 463-64 (2006).

229. See Paul A. Samuelson, Proof That Properly Anticipated Prices Fluctuate Randomly, 6 INDUS. MGMT. REV. 41 (1965).

MANAGEMENT 215 (1989)

230. See, e.g., FRANK K. REILly, INVESTMENT ANALYSIS AND PORTFOLIO

231. See ANDREW W. Lo \& JaSmina HaSanhodzIC, THE EVOlution OF TECHNICAL ANAlysis: Financial Prediction from Babylonian TABlets to BloOMberg TeRminals 150 (2010).

232. See id.

233. See Eugene F. Fama, The Behavior of Stock-Market Prices, 38 J. Bus. 34, 34 (1965); Eugene F. Fama, Random Walks in Stock Market Prices, Fin. AnAlysts J., Sept./Oct. 1965, at $55,56-57$.

234. See Tenn. Gas Pipeline Co. v. FERC, 926 F.2d 1206, 1211 (D.C. Cir. 1991) (citing Douglas K. Pierce \& V. Vance Roley, Stock Prices and Economic News, 59 J. BUS. 49 (1985)).

235. Basic, Inc. v. Levinson, 485 U.S. 224, 246-47 (1988). Violations of section 10(b) of the Securities and Exchange Act of 1934, 15 U.S.C. $\$ 78 \mathrm{j}(\mathrm{b})(2018)$, and Securities and Exchange Commission Rule 10b-5, 17 C.F.R. $\$ 240.10$ b-5 (2017), support an implied private cause of action. See, e.g., Amgen Inc. v. Conn. Ret. Plans \& Trust Funds, 568 U.S. 455, 460-61 (2013); Stoneridge Inv. Partners, LLC v. Scientific-Atlanta, Inc., 552 U.S. 148, 158 (2008); Blue Chip Stamps v. Manor Drug Stores, 421 U.S. 723, 730 (1975).

236. Halliburton Co. v. Erica P. John Fund Inc., 134 S. Ct. 2398, 2420 (2014) (Thomas, J., concurring in the judgment) (citing Lynn A. Stout, The Mechanisms of Market Inefficiency: An Introduction to the New Finance, 28 J. CORP. L. 635, 640 \& n.24 (2003); Fama, Efficient Capital Markets: A Review of Theory and Empirical Work, supra note 225, at 388). 
Despite criticism that this presumption rests on unfounded acceptance of efficiency, ${ }^{237}$ the Supreme Court has declined to recognize "the kind of fundamental shift in economic theory that could justify overruling" the fraud on the market rule. ${ }^{238}$ The Court continues "to presume that most investors knowing that they have little hope of outperforming the market in the long run based solely on their analysis of public available information - will rely on the security's market price as an unbiased assessment of the security's value in light of all public information." 239

These presumptions collide with more sophisticated understandings of investor heterogeneity and of limits on corrective arbitrage. A market "composed solely of information traders" is a market "where price efficiency and the CAPM hold" and where "[r]isk premia are determined solely by beta and distribution of returns on the market portfolio." 240 But markets host sentiment-driven noise traders as well as fully informed, rational traders. ${ }^{241}$ As "noise traders weaken the relation between security returns and beta" and "create a positive conditional correlation between abnormal returns and beta,"242 "steady and forceful" pressure upon "the twin paradigms of price efficiency and the CAPM" compels a "behavioral theory of capital asset prices."243

The rise of indexes and index-based investing ${ }^{244}$ facilitates self-segregation among investors and information-gathering intermediaries. ${ }^{245}$ Even sophisticated agents exhibit herding behavior. ${ }^{246}$ Delays in the diffusion of

237. See, e.g., Edward S. Adams \& David E. Runkle, Solving a Profound Flaw in Fraud-on-the-Market Theory: Utilizing a Derivative of Arbitrage Pricing Theory to Measure Rule 10b-5 Damages, 145 U. PA. L. REV. 1097, 1110-13 (1997); James D. Cox, Understanding Causation in Private Securities Lawsuits: Building on Amgen, 66 VAND. L. REV. 1719, 1732 (2013) (arguing that "friction in accessing public information" and nontrivial "processing costs" prevent markets from incorporating "all public information ... with any quickness at all"); Donald C. Langevoort, Basic at Twenty: Rethinking Fraud on the Market, 2009 WIS. L. REV. 151, 175 ("Doubts about the strength and pervasiveness of market efficiency are much greater today than they were in the mid-1980s."); Baruch Lev \& Meiring de Villiers, Stock Price Crashes and 10b-5 Damages: A Legal, Economic and Policy Analysis, 47 STAN. L. REV. 7, 20-21 (1994).

238. Halliburton Co., 134 S. Ct. at 2410; see also Schleicher v. Wendt, 618 F.3d 679 , 685 ( 7 th Cir. 2010) (recognizing that false statements affect even mispriced stocks).

239. Amgen, 568 U.S. at 462 ; accord Halliburton, 134 S. Ct. at 2411.

240. Hersh Shefrin \& Meir Statman, Behavioral Capital Asset Pricing Theory, 29 J. FIN. \& QUANT. ANALYSIS 323, 323 (1994).

241. See, e.g., Fischer Black, Noise, 41 J. FIN. 529 (1986); Malcolm Baker \& Jeffrey Wurgler, Investor Sentiment in the Stock Market, J. ECON. PERSP., Spring 2007, at 129.

242. Shefrin \& Statman, supra note 240, at 346; Merritt B. Fox et al., Containing Systemic Risk by Taxing Banks Properly, 35 YALE J. ON REG. 67 (2018).

243. Shefrin \& Statman, supra note 240, at 323. See generally Allan W. Kleidon, Anomalies in Financial Economics: Blueprint for Change?, 59 J. BUS. 469 (1986) (describing how anomalies spur theoretical advances).

244. See Anand M. Vijh, S\&P 500 Trading Strategies and Stock Betas, 7 REV. FIN. STUD.

215 (1994).

(2003).

245. See Nicholas Barberis \& Andrei Shleifer, Style Investing, 68 J. FIN. ECON. 161

246. See, e.g., Ian Ayres \& Joshua Mitts, Anti-Herding Regulation, 5 HARV. BUS. L. REV. 1 (2015); Kenneth A. Froot et al., Herd on the Street: Informational Efficiencies in a Market with Short-Term Speculation, 47 J. FIN. 1461 (1992); David B. Scharfstein \& Jeremy C. Stein, Herd Behavior 
information affecting prices imply that some stock groups - including utility stocks as a distinct asset class - "incorporate new information at different rates." 247 Observed delays in the diffusion of information implies that noise trader risk diminishes the corrective potential of arbitrage. ${ }^{248}$

\section{B. Comparable Earnings}

One final aspect of Tennessee Gas offers insight into the relationship between Bluefield's attracting investment and comparable earnings standards. FERC relied exclusively on interest-sensitive "estimates of ... [the] cost of equity capital." ${ }^{249}$ FERC made no effort to "measure [the] industry rate of return or" the pipeline's "relative risk within the industry." 250

But such evidence was available. Company-specific factors, beyond interest rate changes, might have reflect changes in business or financial risk affecting the utility's cost of capital. "[C]ompany-specific risk" through a substantial increase in "the spread between Tenneco's bond yields and the riskfree yield" indicated "that investors thought Tenneco was becoming riskier."251 Failure to address this evidence compounded FERC's vulnerability, 252 particularly in light of precedent distinguishing purely interest-sensitive adjustments in regulatory rate-of-return determinations ${ }^{253}$ from the consideration of firm-specific factors affecting earnings or dividends. ${ }^{254}$

This aspect of Tennessee Gas clarifies the relationship between utility stock and the bond markets. The relevant corner of fixed-income markets is not Treasuries, but corporate bonds derided as "junk." ${ }^{255}$ High-yield bonds correlate closely to equities and bear similar risks. ${ }^{256}$ Low-rated corporate debt with high

and Investment, 80 AM. ECON. REV. 465 (1990); $c$. Richard W. Sias, Institutional Herding, 17 REV. FIN. STUD. 165 (2004) (concluding that institutional investors herd by inferring information from each other's trades).

247. Nicholas Barberis et al., Comovement, 75 J. FIN. ECON. 283, 298 (2005).

248. Compare J. Bradford DeLong et al., Noise Trader Risk in Financial Markets, $98 \mathrm{~J}$. POL. ECON. 703, 705 (1990) (recognizing that the depth and duration of uninformed trading can disrupt arbitrage), with Andrei Shleifer \& Robert Vishny, The Limits of Arbitrage, 52 J. FIN. 35 (1977) (describing limits on the ability to exploit misinformed or irrational behavior). See generally Kenneth R. French \& Richard Roll, Stock Return Variances: The Arrival of Information and the Reaction of Traders, 17 J. FIN. ECON. 5 (1986) (describing the price effects of uninformed demand).

249. Tenn. Gas Pipeline Co. v. FERC, 926 F.2d 1206, 1212 (D.C. Cir. 1991).

250. Id. at 1213

251. Id. at 1210 .

252. See id. at 1212 .

253. See Bos. Edison Co. v. FERC, 885 F.2d 962, 967 (1st Cir. 1989).

254. See Union Elec. Co. v. FERC, 890 F.2d 1193, 1201-04 (D.C. Cir. 1989).

255. See Frank K. Reilly \& David J. Wright, An Analysis of High-Yield Bond Benchmarks, J. FIXED INCOME, March 1994, at 6, 7 (describing high-yield bonds as "low-quality credits that have characteristics of common stocks").

256. See, e.g., Edward I. Altman \& Scott Nammacher, The Default Rate Experience on High-Yield Corporate Debt, FIN. ANALYSTS J., July/Aug. 1985, at 25; Martin S. Fridson, Do High-Yield Bonds Have an Equity Component?, FIN. MGMT., Summer 1994, at 82; Murali Ramaswami, Hedging the 
default risk exhibits informational efficiency similar to its issuer's stocks. ${ }^{257}$ High-yield bonds, coarsely speaking, are "equity in drag. ${ }^{" 258}$ More elegantly: "A low-grade bond can be viewed as a hybrid security consisting of a government bond and a claim on the issuing firm's equity." 259

Decomposing return on utility stock into bond-like and equity-like components proves critical in explaining the relationship between Bluefield's "attracting investment" and "comparable earning" standards. According to Harold Leventhal's review ${ }^{260}$ of Willcox $v$. Consolidated Gas Co., ${ }^{261}$ Consolidated and its regulators had agreed "that the Constitution guaranteed" a "return available without risk, such as return from government obligations."262 Treasury bonds as risk-free securities set a crucial benchmark in ratemaking and utility valuation.

Despite ultimately reversing, the Supreme Court adopted the economic analysis developed at trial. "One who invests his money in a business of a somewhat hazardous character" has "the right to a larger return, without legislative interference, than can be obtained from an investment in government bonds or other perfectly safe security."263 Beyond this baseline, regulation reduced "investment risk in a gas company ... almost to a minimum." "264 Equity in Consolidated, thanks to its lawful "monopol[y] [on] the gas service of the largest city in America," represented as "secure [an] investment as can be imagined with regard to any private manufacturing business."265

From Willcox to the 1968 Permian Basin Area Rate Cases, ${ }^{266}$ the comparable earnings standard displaced "earnings-price ratio computations."267 "[C]omparative risk analysis" can be based on statistical evidence that "the ratio of market price to book value of equity shares varies directly with positive risk (growth possibilities) and inversely with negative risk (possibility of a decline in

Equity Risk of High-Yield Bonds, FIN. ANALYSTS J., Sept./Oct. 1991, at 41; Frank K. Reilly \& David J. Wright, Unique Risk-Return Characteristics of High-Yield Bonds, J. FIXED INCOME, Sept. 2001, at 65.

257. See Dale L. Domian \& William R. Reichenstein, Return-Based Analysis of HighYield Bonds, J. FIXED INCOME, Spring 2008, at 72; Edith S. Hotchkiss \& Tavy Ronen, The Informational Efficiency of the Corporate Bond Market: An Intraday Analysis, 15 REV. FIN. STUD. 1325, 1348-52 (2015); see also id. at 1338-40, 1347 (finding that stocks do not lead high-yield bonds in assimilating information, which is quickly incorporated into prices in both asset classes).

258. Jeremy I. Bulow et al., Distinguishing Debt from Equity in the Junk Bond Era, in DeBt, TAXES, AND CORPORATE REsTRUCTURING 135 (John B. Shoven \& Joel Waldfogel eds., 1990).

259. Hilary Shane, Comovements of Low-Grade Debt and Equity Returns of Highly Leveraged Firms, J. FIXED INCOME, March 1994, at 79.

260. See Consol. Gas Co. v. City of N.Y., 157 F. 849 (C.C.S.D.N.Y. 1907), rev'd sub nom. Willcox v. Consol. Gas Co., 212 U.S. 19 (1909).

261. 212 U.S. 19 (1909).

262. Leventhal, supra note 187, at 996; see also id. at $995 \mathrm{n} .19$ (reporting that federal debt obligations paid interest "from 2 to $4 \%$ depending on the date of flotation and maturity").

263. Willcox, 212 U.S. at 49 .

264. Id.

265. Id.; see also Consolidated, $157 \mathrm{~F}$. at 871 (characterizing the utility as "fairly safe local property" that promised a return "sufficiently above the local mortgage market" to offset uninsurable risk).

266. 390 U.S. 747 (1968).

267. Leventhal, supra note 187 , at 1012 . 
earnings and/or share price). ${ }^{268}$ On these assumptions, "the proper rate of return is that which maintains the company's market-book ratio on the same level as 'alternative investment opportunities," such as indexes of utility companies. ${ }^{269}$

Financial data involving other companies exposed the comparable earnings standard's conceptual weakness. Permian Basin "emphasiz[ed] . . . returns on equity earned by other gas companies" or even by oil producers, whose "revenues ... were admittedly not regulated." 270 The very presence of rate regulation ensures "that there is no company precisely comparable."271 Either "the category of comparative firms is so broad that it includes firms in the unregulated sector," or an exclusive focus on "regulated rates . . . in comparativerisk analysis" renders "the test . . . circular." 272

Nevertheless, market pricing of utility stock promises "a built in selfrighting mechanism," insofar as "changing interest rates or capital-scarcity conditions" will lead investors to "demand a greater or lesser return to hold the stock." $" 273$ By displacing a solipsistic, firm-specific focus, comparable earnings approaches forced regulators to evaluate accounting-based assessments such as the prudent investment rule or DCF in light of government bonds yields and equity premiums for regulated and unregulated firms.

Before modern portfolio theory, ${ }^{274}$ "finance theory was little more than a collection of anecdotes, rules of thumb, and manipulations of accounting data,"275 The law of regulated industries anticipated two of the "most interesting applications of probability and optimization theory" in finance ${ }^{276}$ : the efficient market hypothesis and the capital asset pricing model (CAPM). Part V now explores the CAPM and its application to rate regulation.

\section{The Capital Asset Pricing Model}

\section{A. DCF and CAPM as Benchmarks Within a Zone of Reasonableness}

Standard regulatory practice often deploys comparable earnings methodologies in tandem with DCF analysis to establish a "zone of reasonableness" for a utility's "rate of return on equity." ${ }^{\text {"277 }}$ Consistent with the

268. Gelhaus \& Wilson, supra note 202, at 290.

269. Id. at 290-91.

270. Leventhal, supra note 187 , at 1012 .

271. Gelhaus \& Wilson, supra note 202, at 291.

272. Id.

273. Id. at 295 .

274. See, e.g., EDWIN J. ElTON ET AL., MODERN PORTFOlIO THEORY AND INVESTMENT ANALYSIS (9th ed. 2014); Edwin J. Elton \& Martin J. Gruber, Modern Portfolio Theory, 1950 to Date, 21 J. BANKING \& FIN. 1743 (1997).

275. Robert C. Merton, A Simple Model of Capital Market Equilibrium with Incomplete Information, 42 J. FIN. 483, 483 (1987).

276. Merton, supra note 275 , at 483.

277. Williston Basin Interstate Pipeline Co. v. FERC, 165 F.3d 54, 57 (D.C. Cir. 1999); accord N.C. Utils. Comm'n v. FERC, 42 F.3d 659, 661-62 (D.C. Cir. 1994). 
Gordon growth model, FERC's regulation of oil pipelines uses "a discounted cash flow ... model" to "project[] investor growth expectations over the long term by adding average dividend yields to estimated constant growth in dividends over the indefinite future." 278 FERC "then assigns the pipeline a rate within" the zone of reasonableness as determined by DCF "to reflect specific investment risks associated with that pipeline," relative "to a proxy group of publicly traded companies."279

Reference to a proxy group therefore performs the spatial equivalent of using "long-term growth projection[s]" to normalize distortions otherwise arising from exclusive reliance on "short-term data limited to a narrow segment of the economy." 280 Short-term projections, ceteris paribus, are easier and more reliable. ${ }^{281}$ But long-term projections hedge against "unanticipated developments" that may undermine shorter forecasts. ${ }^{282}$ Checking financial information generated by comparable firms likewise sharpens DCF analyses based on one firm's earnings.

Before 1999, the Florida Public Service Commission supplemented two DCF models applied to a water utility index with two additional comparable earnings benchmarks. ${ }^{283}$ First, the PSC employed a "risk premium model applied to an index of publicly traded natural gas utilities" as a proxy for water and wastewater utilities with less ascertainable financial data. ${ }^{284}$ Second, the Commission used an asset pricing model based on the market return of dividendpaying stocks, the 30-year Treasury Bonds yield, and the average beta" of the water utility index. ${ }^{285}$

In 1999, Florida eliminated historical DCF in favor of "prospective, or forecasted growth rates" based on "the historical trend in dividends."286 The Commission also eliminated risk adjustments extrapolated from the gas industry, which it deemed "no longer a reasonable proxy."287 Critically, the Commission recognized that its "CAPM model, because it is a risk premium model, will appropriately reflect the direction of interest rates as previously indicated by the gas risk premium model." ${ }^{288}$ This use of the CAPM has become prevalent. ${ }^{289}$

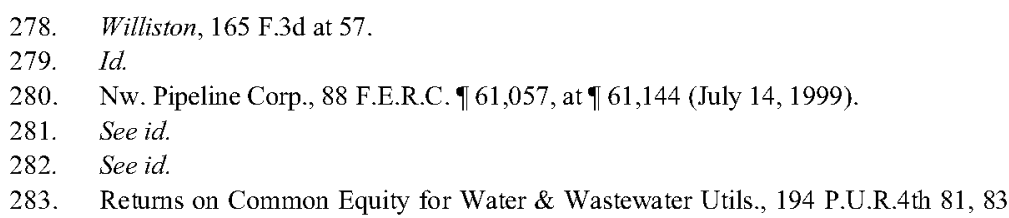

289. See, e.g., AEP Tex. N. Co. v. Surface Transp. Bd., 609 F.3d 432, 434-37, 439-44 (D.C. Cir. 2010); Connect Am. Fund, 28 F.C.C.R. 7123, 7146-69 (2013); Represcribing the Authorized Rate of Return for Interstate Servs. of Local Exch. Carriers, 5 F.C.C.R. 7507 (1990); A. Lawrence Kolbe et al., Measuring Return on Equity Correctly, PUB. UTIL. FORT., Aug. 1, 2005, at 23. 


\section{B. A Formal Description of the CAPM}

The CAPM remains the dominant paradigm in financial risk management. ${ }^{290}$ The development of "general models represent[ing] equivalent approaches to the problem of capital asset pricing under uncertainty" gave rise to today's CAPM. ${ }^{291}$

The capital asset pricing model boasts convenience and "seductive simplicity."292 The CAPM quantifies the premium for shouldering risk in an asset, over a benchmark represented by the return on a risk-free investment:

$$
r_{a}=r_{f}+\beta_{a}\left(r_{m}-r_{f}\right)
$$

where $r_{a}, r_{m}$, and $r_{f}$ represent returns on the asset, the broader market and a riskfree investment, and where $\beta_{a}$ represents the individual asset's beta $v i s$ - $\grave{a}$-vis the market portfolio. ${ }^{293}$

Rearrangement yields the following relationship:

$$
r_{m}-r_{f}=\frac{r_{a}-r_{f}}{\beta_{a}}
$$

The left side of this equation represents the risk premium, ${ }^{294}$ the difference between returns on an investment and the risk-free baseline. ${ }^{295}$ The risk premium dictates a firm's cost of capital.

\section{Beta}

Beta provides the simplest measure of undiversifiable risk. ${ }^{296}$ It supplies information on volatility and liquidity in the broader marketplace. While measuring co-movement between a single security and the market as a whole, beta does not "assum[e] away the existence of interrelationships among securities," but nevertheless "captures a large part of such interrelationships."297

290. See Haim Levy, The Capital Asset Pricing Model IN The 21 St Century: ANalytiCal, EMPIRICAL, ANd BeHAVIORAL PERSPECTIVES 4-5 (2012).

291. Eugene Fama, Risk, Return, and Equilibrium: Some Clarifying Comments, 23 J. FIN. 29, 40 (1968).

292. Eugene F. Fama \& Kenneth R. French, The Capital Asset Pricing Model: Theory and Evidence, J. ECON. PERSP., Summer 2004, at 25, 44.

293. See Robert A. Korajczyk, Introduction, in ASSET PRICING AND PORTFOLIO PERFORMANCE: MODELS, STRATEGy AND PERFORMANCE METRICS, at viii, xv (Robert A. Korajczyk ed., 1999).

294. See id.

295. See William F. Sharpe, Capital Asset Prices: A Theory of Market Equilibrium Under Conditions of Risk, 19 J. FIN. 425, 426 (1964).

296. See, e.g., Jack L. Treynor, How to Rate Management of Investment Funds, 43 HARV. BUS. REV. 63, 66 (1965).

297. William F. Sharpe, A Simplified Model for Portfolio Analysis, 9 MGMT. SCI. 277, $281(1963)$ 
Beta of 1 indicates an asset whose sensitivity to risk is the same as the broader market's. ${ }^{298}$ Positive values for beta below 1 indicate an asset that moves in the market's direction, but is not as sensitive. ${ }^{299}$ Higher beta signals the need for a higher return to attract investment in a presumably riskier company. ${ }^{300}$

Beta is a measure of systematic covariance. ${ }^{301}$

$$
\beta_{y}=\frac{\operatorname{cov}(x, y)}{\operatorname{var}(x)}=\frac{\operatorname{cov}(x, y)}{\sigma_{x}^{2}}
$$

Beta reports the relationship between returns on a single asset and returns on the tradable universe.$^{302}$ Beta as correlated relative relativity is the product of (1) the ratio of asset-specific volatility to market-wide volatility and (2) the correlation between asset-specific and market-wide returns: ${ }^{303}$

$$
\beta_{a}=\frac{\sigma_{a}}{\sigma_{m}} \rho(a, m)=\frac{\sigma_{a}}{\sigma_{m}} \cdot \frac{\operatorname{cov}(a, m)}{\sigma_{a} \sigma_{m}}=\frac{\operatorname{cov}(a, m)}{\sigma_{m}^{2}}=\frac{\left\langle\left(x_{a}-\mu_{a}\right)\left(x_{m}-\mu_{m}\right)\right\rangle}{\left\langle\left(x_{m}-\mu_{m}\right)^{2}\right\rangle}
$$

These elaborations of the CAPM make it easy to understand ratemaking as asset pricing. Specifically designating an index of water utilities as the target asset class yields a pricing model for water and wastewater utilities: ${ }^{304}$

$$
r_{u}=r_{f}+B_{u}\left(r_{u}-r_{f}\right)
$$

$r_{u}:$ "Investor's required rate of return"

$r_{f}$. "Risk-free rate (Blue Chip forecast for 30-year Treasury bond)"

$\beta_{u}$ : "Measure of industry-specific risk (Average for water utilities followed by Value Lines)"

$r_{m}:$ "Market return"

298. See MARK LEVINSON, GUIDE TO FINANCIAL MARKETS 148 (4th ed. 2006).

299. See id.

300. See, e.g., Korajczyk, supra note 293, at xv; William F. Sharpe, Capital Asset Prices: A Theory of Market Equilibrium Under Conditions of Risk, 19 J. FIN. 425, 427-28 (1964).

301. See, e.g., Irwin Friend \& Marshall Blume, Measure of Portfolio Performance Under Uncertainty, 60 AM. ECON. REV. 561, 565 (1970).

302. See, e.g., SHANNON P. PRATT \& ROGER J. GRABOWSKI, COST OF CAPITAL: APPLICATIONS AND EXAMPLES 305-06 (4th ed. 2010).

303. See, e.g., MARTIN L. LEIBOWITZ ET AL., THE ENDOWMENT MODEL OF INVESTING: RETURN, RISK, AND DIVERSIFICATION 14 (2010); MICHAEL B. MILLER, MATHEMATICS AND STATISTICS FOR FINANCIAL RISK MANAGEMENT 198, 213, 292 (2d ed. 2014).

304. Returns on Common Equity for Water \& Wastewater Utils., 194 P.U.R.4th 81, 89 (Fla. Pub. Serv. Comm'n, June 21, 1999). 
The capital asset pricing model suffers from many weaknesses. Most critically, beta is not positively related to returns on stock. ${ }^{305}$ Returns are skewed $^{306}$ and exhibit heavier than normal tails. ${ }^{307}$ Many risks follow abnormal, non-Gaussian distributions. ${ }^{308}$ Large swings of $3 \sigma$ to $6 \sigma$ occur so often that "[e]xtreme price swings are the norm in financial markets - not aberrations." The maximum price change in the American stock market from 1871 to 2010 was "a "ten-sigma event," whose probability under "a normal distribution" would be "less than once in the life of the universe." 310

But attacks on "standard deviation and its variations" as measures of risk in "non-normal distributions" have failed to dislodge beta, ${ }^{311}$ if only because "relatively little effort has been made" to devise "a better risk measure." 312 Beta's leading nemesis has conceded that "market professionals (and academics) still think about risk in terms of market $\beta .,{ }^{, 313}$ Even models purporting to deprecate beta as "insignificant" continue to treat beta as "an important explanatory variable," despite refusing to treat beta as "the main explanatory variable." 314

The CAPM thrives despite academic attacks. "It takes a better theory to kill an existing theory," and finance has "yet to see [a] better theory." 315 Empirical support for other asset-pricing models is not better and "the economic

305. See, e.g., Fama \& French, The Cross-Section of Expected Stock Returns, supra note 225; Marc R. Reinganum, A New Empirical Perspective on the CAPM, 16 FIN. \& QUANT. ANALYSIS 439 (1981); Seha M. Tinic \& Richard R. West, Risk and Return: January vs. the Rest of the Year, 13 J. FIN. ECON. 561 (1983).

306. See, e.g., Felipe M. Aparicio \& Javier Estrada, Empirical Distributions of Stock Returns: European Securities Markets, 1990-95, 7 EUR. J. FIN. 1 (2001); Pornchai Chunhachinda, et al., Portfolio Selection and Skewness: Evidence from International Stock Markets, 21 J. BANKING \& FIN. 143 (1997); Amado Peiró, Skewness in Financial Returns, 23 J. BANKING \& FIN. 847 (1999).

307. See, e.g., Harry M. Markowitz \& Nilufer Usmen, The Likelihood of Various Stock Market Return Distributions, Part 1: Principles of Inference, 13 J. RISK \& UNCERTAINTY 207 (1996); Harry M. Markowitz \& Nilufer Usmen, The Likelihood of Various Stock Market Return Distributions, Part 2: Empirical Results, 13 J. RISK \& UnCERTAINTY 221 (1996); Terence C. Mills, Modelling Skewness and Kurtosis in the London Stock Exchange FT-SE Index Return Distributions, 44 STATISTICIAN 323 (1995).

308. See, e.g., CAMPBELl ET AL., supra note 99, at 17, 81, 172, 498.

309. Benoit B. MANDElbrot \& Richard L. Hudson, THE (Mis)Behavior of MARKETS: A FRACTAL VIEW OF RISK, RUIN, AND REWARD 18 (2004).

310. Nordhaus, supra note 140 , at 242 (analyzing monthly stock changes over that 140 year period).

311. Guy Kaplanski, Traditional Beta, Downside Risk Beta and Market Risk Premiums, 44 Q. REV. ECON. \& FIN. 636, 637 (2004).

312. Id

313. Eugene F. Fama, Efficient Capital Markets: II, 46 J. FIN. 1575, 1593 (1991); accord Glenn N. Pettengill et al., The Conditional Relation Between Beta and Returns, 30 J. FIN. \& QUANT. ANALYSIS 101, 102 (1995).

314. LEVY, supra note 290 , at 4 (emphasis in original); cf. Robert C. Merton, On Estimating the Expected Return on the Market: An Exploratory Investigation, 8 J. FIN. ECON. 323, 324 (1980) (" $[\mathrm{I}] \mathrm{n}$ all ... models, the market risk of a security will affect its equilibrium expected return, and indeed, for most common stocks, market risk will be the dominant factor.").

315. Tim Koller et al., Valuation: Measuring and Managing the Value of COMPANIES 261 (5th ed. 2010). 
importance of the empirical evidence against the CAPM . . is ambiguous. ${ }^{316}$ Courts continue to think of risk and asset pricing in terms of the CAPM ${ }^{317}$ The "concept of beta risk" represents "the single most important contribution of academic researchers" to finance. ${ }^{318}$

\section{Utility Regulation as a Speculative Undertaking in Its own Right}

The persistence of competing rules for utility valuation and rate-of-return determinations demonstrates the uncertainty inherent in regulation. "[N]either law nor economics has yet devised generally accepted standards . . ." ${ }^{319}$ Utility regulation "will always [raise] ... embarrassing question[s]" of indeterminacy and inefficacy. ${ }^{320}$

Public utility law does bear an obligation to ensure an adequate return on private investment. ${ }^{321}$ The investment-backed expectations of utility shareholders are based strictly on opportunity cost. "Any investor paying attention" to the law must "realize that he [cannot] rely indefinitely on traditional regulatory methods." 322 "[R]egulatory measures are temporary expedients, not eternal verities." 223 Because the "Constitution does not bind rate-making bodies to the service of any single formula or combination of formulas, ${ }^{324}$ regulated firms "have no vested interest in any particular [ratemaking] calculation." 325

316. Ravi Jagannathan \& Zhenyu Wang, The Conditional CAPM and the CrossSection of Expected Returns, 51 J. FIN. 3, 4 (1996) (footnote omitted).

317. See, e.g., In re Am. Classic Voyages Co., 367 B.R. 500, 513 n.19 (D. Del. Bankr. 2007) ("While there are other models to determine equity, CAPM is probably the most widely used." (quoting Peter V. Pantaleo \& Barry W. Ridings, Reorganization Value, 51 BUs. LAw. 419, 433 n.52 (1996))

318. Louis K.C. Chan \& Josef Lakonishok, Are Reports of Beta's Death Premature?, J. PORTFOLIO MGMT., Summer 1993, at 5, 51; see also Jagannathan \& Wang, supra note 316, at 4 ("The CAPM is widely viewed as one of the two or three major contributions of academic research to financial managers during the postwar era."). See generally Haim Levy, The CAPM Is Alive and Well: A Review and Synthesis, 16 EUR. FIN. MGMT. 43 (2009).

319. Permian Basin Area Rate Cases, 390 U.S. 747, 790 (1898); accord Duquesne Light Co. v. Barasch, 488 U.S. 299, 308 (1989).

320. Smyth v. Ames, 169 U.S. 466, 546 (1898); accord Duquesne, 488 U.S. at 308.

321. See Fed. Power Comm'n v. Hope Nat. Gas Co., 320 U.S. 591, 603 (1944); Bluefield Waterworks \& Improvement Co. v. Public Serv. Comm'n, 262 U.S. 679, 692-93 (1923); City of Chi. v. Fed. Power Comm'n, 458 F.2d 731, 750-51 (D.C. Cir. 1971), cert. denied, 405 U.S. 1074 (1972).

322. Verizon Commc'ns Inc. v. FCC, 535 U.S. 467, 528 (2002) (describing regulatory discretion as constrained solely by the "constitutional bar against confiscatory rates").

323. Fed. Power Comm'n v. E. Ohio Gas Co., 338 U.S. 464, 489 (1950) (Jackson, J., dissenting).

324. Fed. Power Comm'n v. Nat. Gas Pipeline Co., 315 U.S. 575, 586 (1942); accord Permian Basin Area Rate Cases, 390 U.S. at 776-77 ("[R]ate-making agencies are not bound to the service of any single regulatory formula; they are permitted ... to make the pragmatic adjustments which may be called for by particular circumstances." (quotation omitted)).

325. Farmers Union Cent. Exch., Inc. v. FERC, 734 F.2d 1486, 1517 (D.C. Cir. 1984). 
Ratemaking principles require simply that the "determination of fair prices" be "based on reasonable financial requirements." 326

"[T] he notion of lawfulness requires ... that the chosen framework" for rate regulation "not collapse in practice into a standard-less exercise of Commission discretion resting on no more than an assertion of "expertise." "\$327 "[T]he principle that "lower is better," when presented as "an argument that seems to have no end and little connection to any stated purpose," provides no basis for affirming a ratemaking decision. ${ }^{328}$ Regulators must justify any particular methodological choice as an "appropriate rate reduction measure." 329

Concededly, "a reviewing court must generally be at its most deferential" when an agency "is making predictions, within its area of special expertise, at the frontiers of science." ${ }^{330}$ But review of administrative decisions routinely requires judges to "acquire the learning pertinent to complex technical questions in such fields as economics, science, technology and psychology."331 To leave all "to the skill of experts" is to deny that "[e]xpertise is a rational process and a rational process implies expressed reasons for judgment." 332 Judges "should not automatically succumb" to regulators" "acknowledged expertise ... overwhelmed as it were by ... utter 'scientificity.",333 "Restraint, yes, abdication, no." 334

Exclusive reliance on market forces abjures legal responsibility. "[T]he prevailing price in the marketplace cannot be the final measure of "just and reasonable rates ...."335 Having chosen to "subject[] producers to regulation because of anticompetitive conditions in the [gas] industry, Congress could not

326. Wisconsin v. Fed. Power Comm'n, 373 U.S. 294, 298-99 (1963); accord Duquesne Light Co. v. Barasch, 488 U.S. 299, 315 (1989).

327. Tenn. Gas Pipeline Co. v. FERC, 926 F.2d 1206, 1209 (D.C. Cir. 1991); see also Greater Boston T.V. Corp. v. FCC, 444 F.2d 841, 850-52 (D.C. Cir. 1970).

328. Ass'n of Oil Pipe Lines v. FERC, 281 F.3d 239, 244 (D.C. Cir. 2002).

329. Tex. Office of Pub. Util. Counsel v. FCC, 265 F.3d 313, 329 (5th Cir. 2001), cert. denied, 535 U.S. 986 (2002).

330. Baltimore Gas \& Elec. Co. v. Nat. Res. Def. Council, Inc., 462 U.S. 87, 103 (1983); see also, e.g., Indus. Union Dep't v. Am. Petrol. Inst., 448 U.S. 607, 656 (1980) (plurality opinion); id. at 705-06 (Marshal1, J., dissenting).

331. Ethyl Corp. v. EPA, 541 F.2d 1, 69 (D.C. Cir. 1976) (en banc) (Leventhal, J., concurring), cert. denied, 426 U.S. 941 ; cf. Kassel v. Consol. Freightways Corp., 450 U.S. 662,670 (1981) (plurality opinion) (expressing willingness to invalidate "marginally" effective and "substantially" obtrusive laws despite regulators' claimed expertise over "public health or safety").

332. Fed. Power Comm'n v. Hope Nat. Gas Co., 320 U.S. 591, 627 (1944) (Frankfurter, J., dissenting).

333. Essex Chem. Corp. v. Ruckelshaus, 486 F.2d 427, 434 (D.C. Cir. 1973); cf. Jackson v. Pollion, 733 F.3d 786, 787 (7th Cir. 2013) (Posner, J.) (identifying "a widespread, and increasingly troublesome, discomfort among lawyers and judges confronted by a scientific or other technological issue"); Edward K. Cheng, Fighting Legal Innumeracy, 17 GREEN BAG 2D 271, 276 (2014) (urging all "legal actors .... to demand, without embarrassment, that quantitative researchers not only explain the conclusions of their studies, but also how and why the methods work").

334. Ethyl, 541 F.2d at 69 (Leventhal, J., concurring).

335. Fed. Power Comm'n v. Texaco Inc., 417 U.S. 380, 397 (1974). 
have assumed that 'just and reasonable' rates could conclusively be determined by reference to market price." 336

The obligation to articulate some defensible basis for a rate finds parallels throughout the law of regulated industries. The power to "modify any requirement" of title II of the Communications $\mathrm{Act}^{337}$ did not include the requirement that carriers file tariffs, ${ }^{338}$ lest "a fundamental revision" create " a scheme of rate regulation only where competition does not exist." 339 To like effect is the admonition that a presumption of competition does not constitute regulation of entry in the public interest. "Merely to assume that competition is bound to be of an advantage, in an industry so regulated and so largely closed ... is not enough." 340

Even broader legal consilience connects regulatory valuation to taxation. Bluefield's two methods (comparable earnings and attracting investment) and Justice Brandeis's prudent investment rule precisely parallel the three recognized methods for valuing real estate in ad valorem taxation. ${ }^{341}$ Property taxation reveals the superiority of Bluefield's standards over prudent investment. "[O]rdinarily the market data approach, guided . . . by actual buyers and sellers of comparable property in the market, is the best guide to market value." 342 The "market price" from "a recent, voluntary, arm's length transaction" between "knowledgeable and willing" parties supplies "very persuasive" if "not conclusive" evidence of value. ${ }^{343}$ The "income approach is the most effective approach in determining the value of investment properties," especially "large office buildings." 344 "Finally ... the cost approach is the least reflective of market value and is used only as a check of the estimates obtained from the other approaches." 345

At least in taxation, exactly three methodologies - comparable earnings, discounted cash flow, and accounting - appear to exhaust the universe of feasible approaches to valuation. All three approaches persist even as the valuation of real property and ecosystem services incorporates large datasets of economic and geographic information. ${ }^{346}$ The question is whether valuation methodologies in

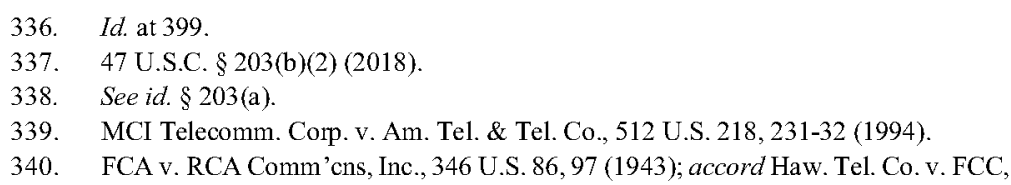

340. FCA v. RCA Comm'cns, Inc., 346 U.S. 86, 97 (1943); accord Haw. Tel. Co. v. FCC, 498 F.2d 771, 776 (D.C. Cir. 1974).

341. See, e.g., Med. Bldg. Land Co. v. Dep't of Revenue, 283 Or. 69, 582 P.2d 416, 421 $\&$ n.10 (1978) (recognizing valuation methods based on sales of comparable parcels, net income generated by investment property, and construction cost net of depreciation); Elli Pagourtzi et al., Real Estate Appraisal: A Review of Valuation Methods, 21 J. PROP. INV. \& FIN. 383 (2003).

342. Med. Bldg. Land Co., 582 P.2d at 421 n.10.

343. Kem v. Dep't of Revenue, 267 Or. 111, 114, 514 P.2d 1335, 1336 (1973)

344. Med. Bldg. Land Co., 582 P.2d at 421 n.10.

345. Id.

346. See, e.g., IAN J. BATEMAN ET AL., APPLIED ENVIRONMENTAL ECONOMICS: A GIS APPROACH TO COST-BENEFIT ANALYSIS (2005); Alastair Adair \& Norman Hutchison, The Reporting of Risk 
utility regulation can exhibit greater creativity, especially as climate change exerts ever greater pressure on the electrical industry.

CSX Transportation, Inc. v. Georgia Board of Equalization ${ }^{347}$ illustrates the relationship between valuation standards in regulation and taxation. In CSX, an appraiser "used three different valuation techniques - the discounted cashflow approach, a market multiple approach, and a stock and debt approach"- to derive estimates for railroad property "ranging from $\$ 8.126$ billion to $\$ 12.346$ billion." 348 These three approaches correspond to Bluefield's attracting investment and comparable earnings standards and to the contemporary synthesis of these standards within the CAPM.

CSX hinged not on the validity of these methods, but on their application. The appraiser "subtract[ed] . . \$ \$400 million" from $\$ 8.126$ billion "to account for intangible property not subject to ad valorem taxation" and thereby "settled on $\$ 7.8$ billion as his final estimate." ${ }^{349}$ Despite agreeing in principle with the state's valuation methodology, ${ }^{350}$ the railroad valued its taxable property at $\$ 6$ billion. ${ }^{351}$ Acknowledging "the variation in the state appraiser's market value range," to say nothing of the railroad's competing estimate, the Supreme Court reasoned that "individual [valuation] methods yield sometimes more, sometimes less reliable results" and "can produce substantially different estimates." 352

In regulation as in taxation, the "admittedly complex" task of valuation "is at bottom just 'an issue of fact about possible market prices." "353 Courts "routinely" make "determinations of market value," even "without the benefit of a market transaction." ${ }^{354}$ Far from being a mechanical "matter of mathematics," easily reviewed by "simply . . . doublechecking . . . equations," calculating "true market value is an applied science, even a craft." 355 "To make a fetish of mere accounting is to shield from examination the deeper causes, forces, movements, and conditions which should govern rates."356

in Real Estate Appraisal Property Risk Scoring, 23 J. ProP. INV. \& FIN. 254 (2005); Marcos Pereira Estellita Lins et al., Real Estate Appraisal: A Double Perspective Data Envelopment Analysis Approach, 138 ANNALS OPERATIONS RES. 79 (2005); Robert Peterson \& Kevin Boyle, Out of Sight, Out of Mind? Using GIS to Incorporate Visibility in Hedonic Property Value Models, 78 LAND ECON. 417 (2002).

347. 552 U.S. 9 (2007).

348. Id. at 17 .

349. Id

350. See id. at 14 n.4; CSX Transp., Inc. v. State Bd. of Equalization, 472 U.S. 1281, $1283-$ 84 (11th Cir. 2006), rev'd, 552 U.S. 9 (2007); cf. Burlington N. R.R. Co. v. Okla. Tax Comm'n, 481 U.S. 454,459 (1987) (recognizing that "almost all jurisdictions which apply property taxes to railroads" use a "similar procedure for determining the value of railroad property subject to tax").

351. CSX, 552 U.S. at 15.

352. Id. at 17 .

353. Id. at 19 (quoting Suitum v. Tahoe Reg'l Planning Agency, 520 U.S. 725, 741

(1997)).

354. Suitum, 520 U.S. at 742; accord CSX, 552 U.S. at 19.

355. CSX, 552 U.S. at 16-17.

356. Fed. Power Comm'n v. Hope Nat. Gas Co., 320 U.S. 591, 643 n.40 (1944) (Jackson,

J., dissenting). 
Thoughtful comparison of all ratemaking methods prudent investment, DCF, comparable earnings, and the CAPM - reveals critical differences along two dimensions. One dimension is temporal, running from the determinate (if imperfectly recorded or reported) past to an intrinsically uncertain future. Among standards for determining a utility's rate of return, the prudent investment standard alone connects future return to past expenditures. The Gordon growth model demonstrates how DCF analysis can be conducted on the basis of past dividends. But Bluefield's directive that regulators set return so as to "attract investment" spins the temporal arrow toward the future. As securities law warns, past performance is no guarantor of future performance, and future rather than past cash flow dictates stock prices.

The other dimension is economically spatial. The spatial boundary among rate-of-return methodologies falls along a different divide. The prudent investment and DCF methodologies are firm-specific insofar as they rely on economic performance unique to the regulated firm. The value of the comparable earnings standard lies in its directive that regulators look beyond the firm. Industry-wide information, so pivotal in the Permian Basin Area Rate Cases, ${ }^{357}$ represented a logical step toward the consideration of firm-specific, industryspecific, and market-wide information in ratemaking methodologies based on the CAPM.

Temporal and spatial differences in ratemaking methodologies will profoundly affect the pricing of future utility infrastructure under uncertainty. At this stage in the development of low- and zero-carbon electrical generation, regulators have a very limited set of antecedents. If regulation, like economics itself, is a system for conveying information through prices, then retrospective and firm-specific methodologies offer an initial but ultimately illusory advantage. Prudent investment or DCF analysis based on historical dividend information is almost surely more readily discovered, and with greater confidence, than inquiries into the regulated industry, capital markets, or macroeconomic conditions.

Trouble arises, however, upon the realization that all sources of uncertainty related to low- or zero-carbon electrical infrastructure - changes in climate, energy technologies, the nature of demand for electricity, and the law itself - are forward-looking. Only by striking a prospective perspective and expanding inquiry past firm-specific factors can regulators accurately forecast demand for electricity, its cost drivers, and the willingness of investors to shoulder complex sources of risk. Regulators have no choice but to climb the conceptual progression from forward-looking DCF analysis (using sophisticated variants of the Gordon growth model) to industry-wide or market-wide methodologies exploiting comparable earnings and CAPM data.

The bias against retrospective, firm-specific methodologies and in favor of prospective, spatially broader methodologies arose during Hope Natural Gas, 
the decision rightfully regarded as the genesis of contemporary regulation. Justice Robert Jackson, lauded for "analyz[ing] with particularity the economic and social aspects of natural gas as well as the difficulties which led to the enactment of the Natural Gas Act," ${ }^{358}$ warned against unthinking endorsement of prudent investment methodology. Although "prudent investment" may boast "relative merits for a utility which creates its service merely by its investment," that theory "has no rational application where there is no such relation between investment and capacity to serve." 359

Justice Jackson's criticism supplies a standing admonition against backward-looking regulatory pricing. In forecasting demand for a utility service and the price at which investors will support entry, as with all forward-looking judgments, "there is little more relation between [past] investment and the results than in a game of poker." ${ }^{360}$ Value is measured by what consumers will pay for the output of a business, "not by what [its owner] puts into it."361

Ratemaking amid technological turmoil and existential environmental angst reflects the challenge of investing as a speculative undertaking. All signals combine value and noise. $s=v+e$. Variability in all signals combines expected dispersion with utterly unpredictable uncertainty: $\operatorname{var}(s)=\operatorname{var}(v)+\operatorname{var}(e)$. To match their decisions to market-based judgments of firm value, regulators must abandon their preference for retrospective, firm-specific information and embrace the inescapable uncertainty of evaluating forward-looking, comprehensive economic information.

In an metaphor befitting the tumultuous Anthropocene epoch, the law of regulated industries must now confront its own no-analog future. ${ }^{362}$ All legal doctrines, from fair value in Smyth to the CAPM, remain extant. But environmental, economic, and technological conditions have reshuffled legal principles to such an extent that regulators must manage new circumstances with old tools, but no historical guidance.

Finer points of mathematical finance and constitutional doctrine ultimately yield to practical considerations. "It is not theory ... which counts," after all, "but the impact of the rate order." "363 Administrative consistency matters as much as intellectual cogency. ${ }^{364}$ "An important factor in the cost of capital . . is investor uncertainty regarding future company or regulatory action that affects the components of total return on equity." 365 Because liberalized electricity

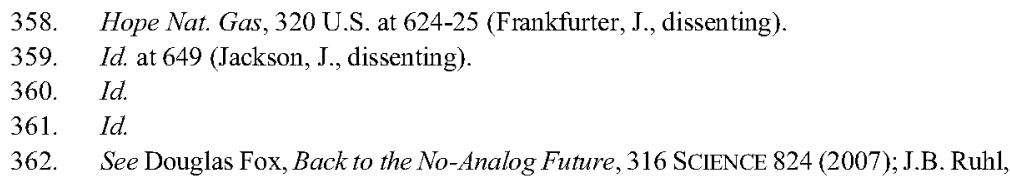

362. See Douglas Fox, Back to the No-Analog Future, 316 SCIENCE 824 (2007); J.B. Ruhl, Climate Change and the Endangered Species Act: Building Bridges to the No-Analog Future, 88 B.U. L. REV. 1 (2008).

363. Hope Nat. Gas, 320 U.S. at 602.

364. Cf. Burnet v. Coronado Oil \& Gas Co., 285 U.S. 393, 406 (1932) (Brandeis, J., dissenting) ("[I]t is more important that the applicable rule of law be settled than that it be settled right.").

365. Gelhaus \& Wilson, supra note 202, at 295 (emphasis added). 
markets are prone to "some periods of high prices and greater differentiation between the prices paid by industrial customers .... and [by] residential customers," this industry faces an elevated risk of political intervention. ${ }^{366}$

Unless capital markets have a clear understanding of regulatory "methods to be employed in calculating total return, this uncertainty becomes an additional risk" factor that will "increase[e] the minimal return that [an investor] demands." 367 Although changes in the physical environment and the arc of technological progress may lie beyond the law, minimizing regulatory uncertainty benefits consumers and the allocation of resources generally. ${ }^{368}$

Legal consistency should bar either firms or their regulators from shifting arbitrarily between ratemaking methodologies. ${ }^{369}$ Such "an exciting new twist" in regulation "invites an enormous amount of gamesmanship." 370 Wholly apart from private firms' motivation to exploit ratemaking rules, regulators face their own behavioral temptation. The asymmetry of regulatory risk may lure agencies into "arbitrarily switch[ing] back and forth between methodologies in a way which require[s] investors to bear the risk of bad investments at some times while denying them the benefit of good investments at others." 371

Ratemaking formulas, whether couched in the logic of prudent investment, $\mathrm{DCF}$, or asset pricing, fall short of offering comprehensive risk management. Even the most elaborate quantitative efforts to "give[] probabilities" for "various outcomes" make "no attempt to explain [the] underlying structure [of] price changes." ${ }^{372}$ Neither regulation nor finance can fully rebut Roll's first critique, the objection that portfolio theory tautologically restates the capital asset pricing model, insofar as any mean-variance efficient portfolio is mathematically equivalent to the CAPM's expected return. ${ }^{373}$

366. David B. Spence, The Politics of Electricity Restructuring: Theory vs. Practice, 40 WAKE FOREST L. REV. 417, 447 (2005); cf. Alexandra B. Klass \& Elizabeth J. Wilson, Interstate Transmission Challenges for Renewable Energy: A Federalism Mismatch, 65 VAND. L. REV. 1801 (2012) (identifying potential conflicts among federal, state, and regional authorities over the connection of renewable energy sources to the transmission grid).

367. Gelhaus \& Wilson, supra note 202, at 295.

368. Id.

369. Cf. Motor Vehicle Mfrs. Ass'n of the U.S. v. State Farm Mut. Auto. Ins. Co., 463 U.S. 29, 48 (1983) ("'A]n agency must cogently explain why it has exercised its discretion in a given manner ....").

370. Farmers Union Cent. Exch., Inc. v. FERC, 74 F.2d 1486, 1525 (D.C. Cir. 1984).

371. Duquesne Light Co. v. Barasch, 488 U.S. 299, 315 (1989). But see Verizon Commc'ns Inc. v. FCC, 535 U.S. 467, 526 (2002) (failing to identify constitutionally significant "reliance interests" that would be "jeopardized by an intentional switch in rate-setting methodologies").

372. DOUglas W. HubBard, THE FAILURE OF RisK MANAGEMENT 67 (2009). But cf.

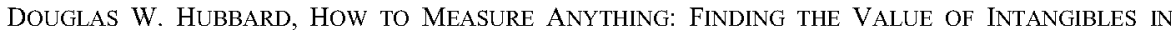
BUSINESS (2007) (using portfolio theory to value anything used in business).

373. See Richard Roll, A Critique of the Asset Pricing Theory's Tests-Part I: On Past and Potential Testability of the Theory, 4 J. FIN. ECON. 129, 136 (1977); see also Fama \& MacBeth, supra note 95 , at 610 . 
Tautologies such as $r=D_{1} / P_{0}+g$, however, do serve useful purposes. What matters is that the tautology be "correct."374 "All models are wrong; some models are useful." ${ }^{\text {375 }}$

DCF and the Gordon growth model epitomize the quest for a rate of return that attracts investment. The CAPM culminates nearly a century of regulatory wisdom garnered while "muddling through" the comparable earnings standard. ${ }^{376}$ Both of Bluefield's ratemaking standards ${ }^{377}$ may be understood in terms of section II.B.1's general model of financial uncertainty.

DCF, the Gordon growth model, and the CAPM are all special cases of the formula, $s=v+e$, which denotes an economic signal $(s)$ as the sum of fundamental value $(v)$ and noise $(e)$. The basic DCF formula, defines the rate of return as the ratio of dividends to share price, plus a less determinate growth factor. Rejecting the unrealistic assumption that investors "live for only one period" connects DCF and the Gordon growth model with more sophisticated models. ${ }^{378}$ Investment-based asset pricing defines the rate of return as a function of corporate earnings and stock returns. ${ }^{379}$ Conceptually, the rate of return should equal the ratio of a vector of future earnings from which a corporation pays dividends to the corresponding vector of capital investments:

$$
r=\frac{\mathbf{e}}{\mathbf{k}}=\frac{e_{1} e_{2} \ldots e_{n-1} e_{n}}{k_{0} k_{1} \ldots k_{n-2} k_{n-1}}
$$

This ratio amalgamates prudent investment with the basic ratio of earnings to price.

The regulatory $\mathrm{CAPM}, r_{u}=r_{f}+\beta_{u}\left(r_{u}-r_{f}\right)$, likewise fits the basic $s=v+e$ formula. The second half of this formula, $\beta_{u}\left(r_{u}-r_{f}\right)$ may be

374. Leventhal, supra note 187 , at 1009 n.72

375. G.E.P. BOX, J. STUART Hunter \& Willlam G. Hunter, Statistics FOR EXPERIMENTERS: DESIGN, INNOVATION, AND DISCOVERY 440 (2d ed. 2005); see also id. at 208, 384; G.E.P. BOX \& NORMAN R. DRAPER, EMPIRICAL MODEL-BUILDING AND RESPONSE SURFACES 74 (1987) ("Remember that all models are wrong; the practical question is how wrong do they have to be to not be useful."); id. at 424 ("Essentially, all models are wrong, but some are useful.").

376. See Charles E. Lindblom, The Science of "Muddling Through", 19 PUB. ADMIN. REV. 79, 86 (1959); cf. Kenneth Culp Davis, A New Approach to Delegation, 36 U. CHI. L. REV. 713,733 (1969) (recommending that agencies accumulate information about regulated industries and follow a "common law" policymaking approach).

377. See Bluefield Water Works \& Improvement Co. v. Pub. Serv. Comm'n, 262 U.S. $679,692-93(1923)$.

378. Jagannathan \& Wang, supra note 316 , at 4; see Robert C. Merton, An Intertemporal Capital Asset Pricing Model, 41 ECONOMETRICA 867 (1973); John Y. Campbell, Intertemporal Asset Pricing Without Consumption Data, 83 AM. ECON. REV. 487 (1993); Eugene F. Fama, Multifactor Portfolio Efficiency and Multifactor Asset Pricing, 31 J. FIN. \& QUANT. ANALYSIS 44 (1996).

379. See, e.g., John H. Cochrane, Production-Based Asset Pricing and the Link Between Stock Returns and Economic Fluctuations, 46 J. FIN. 209 (1991); Laura Xiaolei Liu et al., InvestmentBased Expected Stock Returns, 117 J. POL. ECON. 1105 (2009). This approach should be contrasted with consumption-based asset pricing. See, e.g., John Y. Campbell \& John H. Cochrane, By Force of Habit: A Consumption-Based Explanation of Aggregate Stock Market Behavior, 107 J. POL. ECON. 205 (1999). Risk premiums unique to utility companies may be reflect macroeconomic pro-cyclicality between demand for utility services and returns on human capital. 
conceptualized as the premium that induces investors to buy utility stock instead of a risk-free Treasury bond. We can express this idea, without loss of generality, through econophysics: If " $[\mathrm{t}]$ he optimal portfolio is . . given by minimizing the risk $\sigma^{2}$, given the return $\bar{r}$," then "risk $\sigma^{2}$ is a quadratic function of the deviation of the portfolio return from that of the riskless asset, $\left(\bar{r}-r_{0}\right)^{2} ., 380$

The inclusion of industry-specific beta within the regulatory CAPM provides a further illustration of generalized economic uncertainty. As a measure of variance within the economic signal that communicates a utility's intrinsic value, beta decomposes into a basic quantum of risk, plus a premium indicating the reliability of the information used to compute beta: $\operatorname{var}(s)=\operatorname{var}(v)+\operatorname{var}(e)$.

Most regulatory applications treat beta as if it were unconditionally reliable. Conceptualizing beta as a special case of information uncertainty, $E_{t} r_{e, t+1}=$ $\gamma V_{t}+\theta M_{t}$ lets us define and quantify the "higher premium" that investors demand under uncertainty. ${ }^{381}$ If we have confidence in our methods for quantifying risk, "so that $M_{t}=0$, or if agents are not averse to uncertainty, so that $\theta=0,{ }^{, 382}$ the more familiar linear regression expressing returns over a risk-free baseline, $E_{t} r_{e, t+1}=\gamma V_{t}$, within the CAPM is recovered as a special case of $E_{t} r_{e, t+1}=\gamma V_{t}+\theta M_{t}$, the formula combining aversion to risk with aversion to uncertainty. ${ }^{383}$ In mathematical as well as metaphorical terms, rate regulation must "wager [its] salvation upon some prophecy based upon imperfect knowledge." 384

380. PETER RICHMOND ET AL., ECONOPHYSICS AND PHYSICAL ECONOMICS $§ 11.2$, at $118(2013)$.

381. Anderson et al., supra note 96 , at 234.

382. Id.

383. Id. at 233-34.

384. Abrams v. United States, 250 U.S. 616, 630 (1919) (Holmes, J., dissenting). 